\title{
You Can't B. cereus - A Review of Bacillus cereus Strains That Cause Anthrax-Like Disease
}

\author{
Victoria M. Baldwin* \\ Dstl, Salisbury, United Kingdom
}

Emerging strains of Bacillus cereus, traditionally considered a self-limiting foodborne pathogen, have been associated with anthrax-like disease in mammals, including humans. The strains have emerged by divergent evolution and, as exchange of genetic material in the Bacillus genus occurs naturally, it is possible that further isolates will be identified in the future. The strains vary in their genotypes and phenotypes, combining traits of both $B$. cereus and $B$. anthracis species. Cases of anthrax-like disease associated with these strains result in similar symptoms and mortality rates as those caused by $B$. anthracis. The strains are susceptible to frontline antibiotics used in the treatment of anthrax and existing vaccines provide protection in animal models. The emergence of these strains has reignited the debate surrounding classification of the $B$. cereus sensu lato group and serves as a reminder that the field of medical microbiology is constantly changing and remains an important and ongoing area of research.

Keywords: Bacillus cereus, Bacillus anthracis, anthrax, emerging disease, virulence plasmid

\section{BACKGROUND}

Bacillus cereus sensu lato (s. l.) is a group of closely related Gram-positive, endospore-forming bacteria. Though genetically similar, these bacteria have diverse phenotypes with significant roles in agriculture, the environment, food spoilage and human and animal health. A pangenome study of the group identified 59,989 different genes, of which 598 were considered "core" genes, defined as being present in $99 \%$ of the genomes analyzed. A total of $45 \%$ of the genes were unique to one strain within the group, which may be a contributing factor to the group's diversity (Bazinet, 2017). The group is broadly divided into three clades, each containing strains of Bacillus cereus sensu stricto (hereafter, B. cereus) and Bacillus thuringiensis (Böhm et al., 2015; Okinaka and Keim, 2016; Bazinet, 2017; Fayad et al., 2019; Figure 1). In addition, Clade 1 contains all strains of Bacillus anthracis and Clade 3 is the most diverse, comprising of several other species; Bacillus weihenstephanensis (Lechner et al., 1998), Bacillus mycoides and Bacillus pseudomycoides (Nakamura, 1998), Bacillus gaemokensis (Jung et al., 2010), Bacillus manliponensis (Jung et al., 2011), Bacillus cytotoxicus (Guinebretière et al., 2013), Bacillus toyonensis (Jiménez et al., 2013), Bacillus bingmayongensis (Liu et al., 2014) and Bacillus wiedmannii (Miller et al., 2016). The clades are further divided into seven subgroups. Phylogenetic organization of the clades and subgroups is largely consistent, irrespective of the method used to define them. These include Bayesian statistics (Didelot et al., 2009) and phenotyping (for example, thermal tolerance) (Guinebretière et al., 2008). Genetic analyses include 16S rRNA gene sequencing (Lapidus et al., 2008), multilocus sequence typing (MLST) 


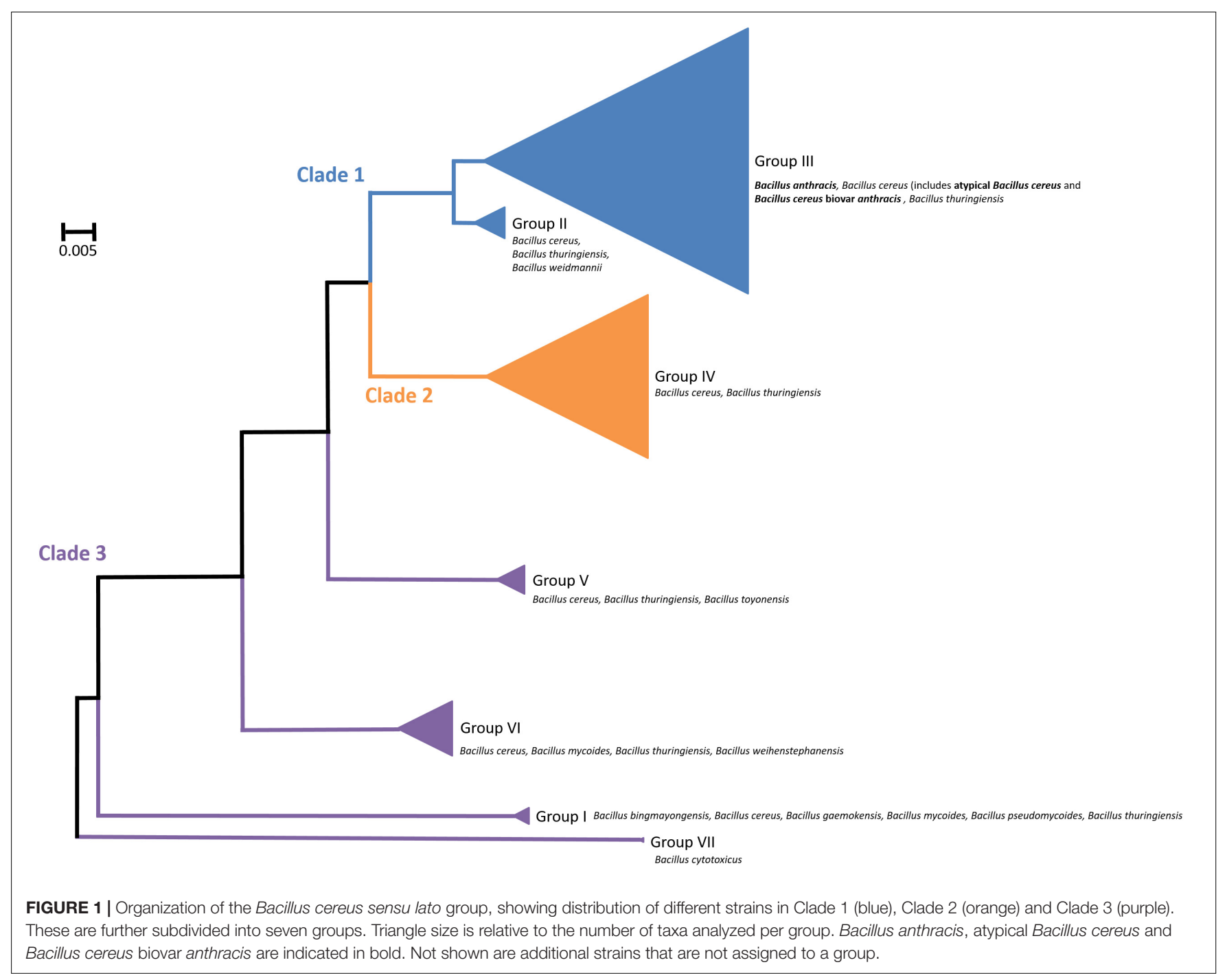

(Didelot et al., 2009), amplified fragment length polymorphisms (AFLP) (Guinebretière et al., 2008; Tourasse et al., 2010), whole genome sequencing of protein-coding genes (Schmidt et al., 2011; Zwick et al., 2012), single nucleotide polymorphisms (SNPs) (Liu et al., 2015), DNA-DNA hybridization (Böhm et al., 2015), pan-genome-wide association studies (Bazinet, 2017) and mobile genetic elements (Fayad et al., 2019).

There has been much debate surrounding the nomenclature of this group of bacteria. Recently, Carroll et al. (2020) proposed a novel taxonomy, reassigning the bacteria into the species Bacillus pseudomycoides, Bacillus paramycoides, Bacillus mosaicus, Bacillus cereus sensu stricto, Bacillus toyonensis, Bacillus mycoides, Bacillus cytotoxicus and Bacillus luti. Further division into subspecies would designate B. anthracis as Bacillus mosaicus subsp. anthracis. Whilst this method may aid clarity, it is yet to be seen whether it will be accepted by the wider scientific community. This is partly due to how deeply the current terminology is ingrained in published literature and day-to-day usage and partly because $B$. anthracis is a significant pathogen with severe consequences to human health and there is a great amount of legislation surrounding possession, use and transport of the bacteria and its products. Therefore, its importance is preserved with the distinction as a separate species.

Strains of $B$. anthracis are nested within Clade 1 of the $B$. cereus s. $l$. group and display little genetic variation (Keim et al., 2009). Differentiating between strains proved difficult until the development of variable number tandem repeat (VNTR) analysis (Jackson et al., 1997; Keim et al., 2000; Lista et al., 2006; Thierry et al., 2014). B. anthracis is a well-studied member of the group due to its role as a highly virulent obligate pathogen of mammals, including humans. Like other endospore-forming bacteria, B. anthracis exists in two states, the vegetative bacilli and a dormant spore. Sporulation occurs in the environment under nutrient-depleted conditions and spores are highly resistant to degradation by factors such as UV light, heat, desiccation, chemical disinfectants and antimicrobial compounds (Swick et al., 2016). Transmission to a host is usually via cutaneous, inhalational and gastrointestinal routes. Within the host, $B$. anthracis spores germinate and form vegetative 
bacteria that are capable of multiplying and producing virulence factors that may result in the potentially fatal disease, anthrax (see Moayeri et al., 2015 for a detailed review of anthrax pathogenesis). An unusual route of infection, via intravenous injection of heroin contaminated with $B$. anthracis spores, caused several deaths in the United Kingdom and wider EU (Brett et al., 2005; Grunow et al., 2012). Spores are able to persist in the environment for long periods of time. This was evidenced by the decades-long contamination of Gruinard Island in Scotland, which was exposed to aerosolised spores of virulent $B$. anthracis in 1942 for research purposes during World War II (Manchee et al., 1981). Viable spores were still recoverable in the 1980s, so extensive treatment of the land with formaldehyde was undertaken to reduce the number of spores to a safe level (determined by safely grazing sheep on the land for 5 months with no fatalities) (Manchee et al., 1994).

In contrast, $B$. cereus strains are spread throughout the $B$. cereus $s$. $l$. group, with pathogenic variations found in Clades 1 and 2. Contamination of food with pathogenic B. cereus is common and can cause spoilage and either emetic or diarrheal foodborne disease in humans, which is usually self-limiting (Wijnands et al., 2006; Fricker et al., 2007; Saleh-Lakha et al., 2017). However, virulence varies greatly, depending on the pathogen strain and host immune status (Chang et al., 2017). For example, $B$. cereus strain IP5832 can be included in probiotics for human consumption (Hoa et al., 2000), whilst other strains cause potentially fatal systemic food poisoning (Dierick et al., 2005; Naranjo et al., 2011; Public Health England, 2014). The two forms of disease are caused by the production of different toxins. Cereulide is associated with emetic symptoms (Agata et al., 2002; Häggblom et al., 2002) and enterotoxin with diarrhea (Granum and Lund, 1997; Senesi and Ghelardi, 2010). B. cereus is also able to form highly resistant spores that persist in the environment that are difficult to remove by traditional methods of decontamination (including cooking). B. cereus has several fundamental phenotypic differences when compared with $B$. anthracis. Unlike B. anthracis, it is typically hemolytic, motile, $\gamma$-phage resistant and penicillin G resistant (Kolstø et al., 2009).

Since 2004, reports of atypical B. cereus strains causing anthrax-like disease in humans and other mammals have emerged. These strains are defined by their $B$. cereus chromosomal DNA and the acquisition of virulence plasmids that are highly similar to the anthrax virulence plasmids pXO1 and pXO2.

Within the B. cereus s. $l$. group these strains appear in Clade 1 (Figure 1). Despite their ability to cause anthrax-like disease, they are more closely related to other $B$. cereus strains than $B$. anthracis (Antonation et al., 2016). There are two variants of $B$. cereus that cause anthrax disease; atypical strains such as G9241, FL2013 and $03 \mathrm{BB} 102$ and B. cereus biovar anthracis (Bcbva) strains such as CA and CI. The Bcbva variants are clustered together, derived from a single branch and their nearest neighbor is $B$. cereus strain ISP3191, which does not cause anthrax-like disease (Antonation et al., 2016). The atypical B. cereus strains can be found across different branches and are evolutionarily further from B. anthracis than Bcbva (Hoffmaster et al., 2006; Antonation et al., 2016). Other close neighbors to both variants include B. cereus E33L, known as Zebra-killer due to its isolation from a zebra carcass and $B$. thuringiensis 97-27 subsp. konkukian serotype $\mathrm{H} 34$, which was isolated from a human with a necrotic wound (Han et al., 2006; Hoffmaster et al., 2006; Klee et al., 2010; Antonation et al., 2016). Figure 2 shows the distribution of atypical and Bcbva strains in relation to B. anthracis Ames, based on the detailed phylogenetic trees published by Antonation et al. (2016) and Pena-Gonzalez et al. (2018).

In humans, isolated cases of pulmonary anthrax-like disease caused by atypical $B$. cereus were confirmed in metal workers from Louisiana and Texas (Hoffmaster et al., 2004, 2006; Avashia et al., 2007; Wright et al., 2011; Pena-Gonzalez et al., 2017). Of the seven total cases, six were ultimately fatal (Table 1). A mortality rate of $86 \%$ [based on a small number of cases $(n=7)]$ is consistent with that observed in pulmonary anthraxlike disease caused by B. anthracis (86-89\%) (Kamal et al., 2011). There may have been earlier incidents of inhalational anthraxlike disease caused by atypical $B$. cereus strains; however, these were not verified at the time (Bekemeyer and Zimmerman, 1985; Miller et al., 1997). The infections and fatalities occurred in immunocompetent men with no known risk factors. However, they were all metal workers and may have been particularly at risk of infection via the inhalation route. Occupational hazards, including high numbers of spores in dust generated and damage to the respiratory tract, could increase their susceptibility to respiratory disease (Antonini et al., 2003). Additionally, two cases of cutaneous anthrax-like disease caused by $B$. cereus have been observed. The first incident occurred in a non-metal worker in Florida with an unknown cause of infection that resulted in development of a characteristic anthrax eschar (Marston et al., 2016). The second case was a lab-acquired infection of B. cereus G9241 in Illinois (Kaiser, 2011.). At least six different strains of atypical B. cereus (G9241, $03 \mathrm{BB} 87$ 03BB102, Elc2, FL2013 LA2007, and LA4726) were responsible for these cases (Hoffmaster et al., 2004, 2006; Avashia et al., 2007; Wright et al., 2011; Marston et al., 2016; Pena-Gonzalez et al., 2017).

Anthrax-like disease associated with $B$. cereus infection has also been identified in other mammals, including chimpanzees, gorillas, monkeys, elephants and various livestock, on large-scales across Western Africa (Leendertz et al., 2004, 2006; Klee et al., 2006; Pilo et al., 2011; Antonation et al., 2016; Hoffmann et al., 2017; Zimmermann et al., 2017). Most B. cereus strains associated with cases of anthrax-like disease in Africa are classified as Bcbva and are distinct from the atypical strains recovered from humans in the United States (Antonation et al., 2016; Hoffmann et al., 2017). However, an unusual strain originally designated B. anthracis JF3964, was isolated from cattle in Cameroon and is distinct from the closely related Bcbva strains despite possessing both pBCXO1 and pBCXO2 virulence plasmids (Tables 1, 3; Pilo et al., 2011; Antonation et al., 2016). Whilst no human infections with Bcbva have been observed, antibodies against Bcbva-specific antigen pXO2-60 have been detected in populations resident in the endemic Taï National Park region of Côte d'Ivoire (Dupke et al., 2020). In this region, a large proportion (38\%) of wildlife mortalities are associated with anthrax-like disease caused by Bcbva (Hoffmann et al., 2017). Despite this, only 5\% of wildlife was found to be seropositive for Bcbva. This low immune 


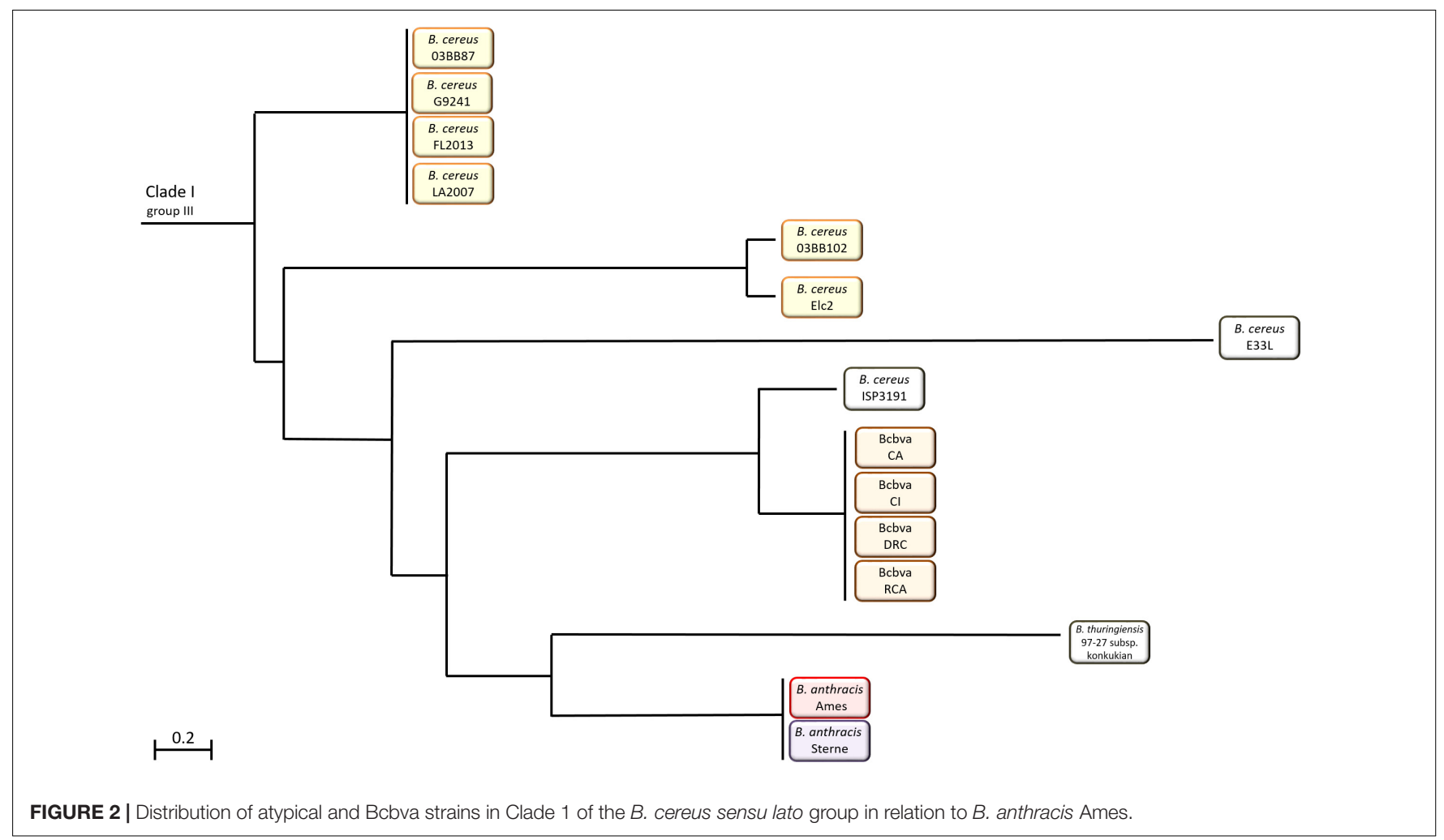

response may contribute to the high number of associated mortalities (Zimmermann et al., 2017).

Several studies have examined the virulence of atypical B. cereus G9241 in various mammalian models (Table 2). It has been shown to cause fatal anthrax-like disease in both immunocompromised and immunocompetent mice and in guinea-pigs, whilst one study demonstrated it is avirulent in New Zealand white rabbits (Wilson et al., 2011). Few studies have directly compared B. cereus $\mathrm{G} 9241$ with a strain of B. anthracis in the same experiment (Hoffmaster et al., 2004; Lever, unpublished data). These studies described similar levels of virulence between B. cereus G9241 and B. anthracis (Sterne and Ames respectively) (Table 2). However, many reports have included comparisons with previously published data, which generally suggests that $B$. cereus G9241 is less virulent than B. anthracis Ames and more virulent than B. anthracis Sterne (Oh et al., 2011; Wilson et al., 2011).

As with B. cereus G9241, experiments have shown that two Bcbva strains (CI and CA) are more virulent than B. anthracis Sterne but slightly less virulent than $B$. anthracis wild type strain 9602 (Brézillon et al., 2015). For example, the calculated $\mathrm{LD}_{50}$ values in outbred mice via the intranasal route were $3.5 \times 10^{4} \mathrm{cfu}$ Bcbva CI, $3.5 \times 10^{4} \mathrm{cfu}$ Bcbva CA, $>1.0 \times 10^{8} \mathrm{cfu}$ B. anthracis 7702 and $1.0 \times 10^{4} \mathrm{cfu}$ B. anthracis 9602 (Brézillon et al., 2015).

\section{VIRULENCE DETERMINANTS}

The emerging atypical B. cereus and Bcbva strains have obtained plasmids that enable expression of virulence factors to cause anthrax-like disease. These are highly related to the anthrax virulence plasmids pXO1 and pXO2. One of the traits that separate atypical B. cereus from Bcbva is that the atypical strains have obtained only one of these plasmids, pBCXO1, whereas Bcbva has obtained both $\mathrm{pBCXO1}$ and $\mathrm{pBCXO} 2$. Several different combinations of chromosomal and plasmid DNA occur in B. anthracis, atypical B. cereus and Bcbva causing anthrax-like disease (Tables 3, 4). The essential requirement for full virulence is the expression of both tripartite anthrax toxin and a capsule (protein or polysaccharide).

\section{Anthrax Toxin}

The anthrax toxin responsible for pathology and eventual fatality during the course of disease is a tripartite $\mathrm{AB}$ toxin comprised of protective antigen (PA), lethal factor (LF) and edema factor $(\mathrm{EF})$. Expression of this toxin is essential for full virulence. The molecular mechanisms of anthrax toxin have been reviewed (Young and Collier, 2007; Moayeri and Leppla, 2009; Friebe et al., 2016). Briefly, PA binds to receptors on the surface of host cells and is cleaved by furin-like proteases. Truncated PA monomers assemble into heptamers and octamers, which embed into the cell membrane, creating a pre-pore formation. LF and EF then bind to the PA oligomers and the entire complex is endocytosed by the cell. The PA oligomer creates a pore in the endosome membrane, enabling release of LF and EF into the host cell cytoplasm. Here, LF functions as a $\mathrm{Zn}^{2+}$-dependent endoprotease, inhibiting mitogen-activated protein kinase kinase (MAP2K) activity, which disrupts cell signaling pathways and induces apoptosis (Klimpel et al., 1994). EF functions as a $\mathrm{Ca}^{2+}$ - and calmodulin-dependent 
TABLE 1 | Atypical and Bcbva strains discussed in this review including their place and source of origin, anthrax-like virulence plasmid content and disease caused.

\begin{tabular}{|c|c|c|c|c|c|c|}
\hline Organism & Country of origin & Host/origin & $\begin{array}{l}\text { Virulence } \\
\text { plasmids }\end{array}$ & Symptoms & Outcome & References \\
\hline $\begin{array}{l}\text { B. cereus } \\
\text { G9241 }\end{array}$ & $\begin{array}{l}\text { Louisiana, } \\
\text { United States }\end{array}$ & $\begin{array}{l}\text { Human; } \\
\text { blood/sputum } \\
\text { (welder, } \\
\text { immunocompetent) }\end{array}$ & $\begin{array}{l}\mathrm{pBCXO1} \\
\mathrm{pBC} 210\end{array}$ & $\begin{array}{l}\text { Fever, chills, } \\
\text { dyspnea, } \\
\text { hemoptysis, } \\
\text { nausea, vomiting, } \\
\text { cough, pneumonia }\end{array}$ & $\begin{array}{l}\text { Pulmonary } \\
\text { anthrax-like disease } \\
\text { requiring intensive } \\
\text { care Recovered }\end{array}$ & $\begin{array}{l}\text { Hoffmaster et al., } \\
2004,2006\end{array}$ \\
\hline $\begin{array}{l}\text { B. cereus } \\
03 \mathrm{BB} 87\end{array}$ & $\begin{array}{l}\text { Texas, } \\
\text { United States }\end{array}$ & $\begin{array}{l}\text { Human; blood } \\
\text { (muller, } 56 \text { years } \\
\text { old, } \\
\text { immunocompetent) }\end{array}$ & $\begin{array}{l}\text { pBCXO1 } \\
\text { pBC210 }\end{array}$ & $\begin{array}{l}\text { Chills, malaise, } \\
\text { cough, hemoptysis, } \\
\text { dyspnea, diarrhea, } \\
\text { fever, pneumonia }\end{array}$ & $\begin{array}{l}\text { Pulmonary anthrax } \\
\text { requiring intensive } \\
\text { hospital treatment } \\
\text { Fatal }\end{array}$ & $\begin{array}{l}\text { Hoffmaster et al., } \\
\text { 2006; Avashia } \\
\text { et al., } 2007\end{array}$ \\
\hline $\begin{array}{l}\text { B. cereus } \\
03 \mathrm{BB} 102\end{array}$ & $\begin{array}{l}\text { Texas, } \\
\text { United States }\end{array}$ & $\begin{array}{l}\text { Human; blood } \\
\text { (welder, } 39 \text { years } \\
\text { old, } \\
\text { immunocompetent) }\end{array}$ & $\begin{array}{l}\text { pBCXO1 } \\
\text { pBC210 }\end{array}$ & $\begin{array}{l}\text { Abdominal pain, } \\
\text { diarrhea, cough, } \\
\text { fever, chills, } \\
\text { vomiting, hypoxia, } \\
\text { pneumonia }\end{array}$ & $\begin{array}{l}\text { Pulmonary anthrax } \\
\text { requiring intensive } \\
\text { hospital treatment } \\
\text { Fatal }\end{array}$ & $\begin{array}{l}\text { Hoffmaster et al., } \\
\text { 2006; Avashia } \\
\text { et al., 2007; } \\
\text { Pena-Gonzalez } \\
\text { et al., } 2018\end{array}$ \\
\hline $\begin{array}{l}\text { B. cereus } \\
\text { Elc2 }\end{array}$ & $\begin{array}{l}\text { Texas, } \\
\text { United States }\end{array}$ & $\begin{array}{l}\text { Human; blood } \\
\text { (welder, } 39 \text { years } \\
\text { old, } \\
\text { immunocompetent) }\end{array}$ & $\mathrm{pBCXO1}$ & $\begin{array}{l}\text { Dyspnea, } \\
\text { hemoptysis, } \\
\text { vomiting, cough, } \\
\text { headache, chest } \\
\text { pain, pneumonia }\end{array}$ & $\begin{array}{l}\text { Pulmonary anthrax } \\
\text { requiring intensive } \\
\text { hospital treatment } \\
\text { Fatal }\end{array}$ & $\begin{array}{l}\text { Wright et al., 2011; } \\
\text { Pena-Gonzalez } \\
\text { et al., } 2018\end{array}$ \\
\hline $\begin{array}{l}\text { B. cereus } \\
\text { FL2013 }\end{array}$ & $\begin{array}{l}\text { Florida, } \\
\text { United States }\end{array}$ & $\begin{array}{l}\text { Human; skin lesion } \\
\text { swab } \\
\text { (non-metal worker, } \\
70 \text { years old, } \\
\text { immunocompetent) }\end{array}$ & $\mathrm{pBCXO1}$ & $\begin{array}{l}\text { Black eschar skin } \\
\text { lesion }\end{array}$ & $\begin{array}{l}\text { Cutaneous anthrax } \\
\text { requiring Antibiotics } \\
\text { in hospital } \\
\text { Recovered }\end{array}$ & $\begin{array}{l}\text { Marston et al., } \\
2016\end{array}$ \\
\hline $\begin{array}{l}\text { B. cereus } \\
\text { LA2007 }\end{array}$ & $\begin{array}{l}\text { Louisiana, } \\
\text { United States }\end{array}$ & $\begin{array}{l}\text { Human; } \\
\text { unknown sample } \\
\text { (welder) }\end{array}$ & $\begin{array}{l}\mathrm{pBCXO1} \\
\mathrm{pBC} 210\end{array}$ & Pneumonia & $\begin{array}{l}\text { Pulmonary anthrax } \\
\text { Fatal }\end{array}$ & $\begin{array}{l}\text { Pena-Gonzalez } \\
\text { et al., } 2017\end{array}$ \\
\hline $\begin{array}{l}\text { B. cereus } \\
\text { G9898 }\end{array}$ & $\begin{array}{l}\text { Louisiana, } \\
\text { United States }\end{array}$ & $\begin{array}{l}\text { Human; } \\
\text { blood/sputum } \\
\text { (two welders, } 41 \\
\text { and } 46 \text { years } \\
\text { old, } \\
\text { immunocompetent) }\end{array}$ & $\begin{array}{l}\text { pBCXO1 } \\
\text { pBC210 }\end{array}$ & $\begin{array}{l}\text { Cough, chills, fever, } \\
\text { hemoptysis, chest } \\
\text { pain, pneumonia }\end{array}$ & $\begin{array}{l}\text { Two cases of } \\
\text { pulmonary anthrax } \\
\text { requiring intensive } \\
\text { hospital treatment. } \\
\text { Both fatal }\end{array}$ & $\begin{array}{l}\text { Miller et al., 1997; } \\
\text { Sue et al., } 2006\end{array}$ \\
\hline $\begin{array}{c}\text { Bcbva } \\
\text { CA }\end{array}$ & $\begin{array}{l}\text { Dja Reserve, } \\
\text { Cameroon }\end{array}$ & $\begin{array}{l}\text { Apes (Chimpanzee } \\
\text { and gorilla) }\end{array}$ & $\begin{array}{l}\mathrm{pBCXO1} \\
\mathrm{pBCXO2}\end{array}$ & $\begin{array}{l}\text { In chimpanzees; } \\
\text { weakness, } \\
\text { vomiting, sudden } \\
\text { death }\end{array}$ & Often fatal & $\begin{array}{l}\text { Leendertz et al., } \\
\text { 2004; Klee et al., } \\
\text { 2006; Klee et al., } \\
2010\end{array}$ \\
\hline $\begin{array}{c}\text { Bcbva } \\
\mathrm{Cl}\end{array}$ & $\begin{array}{l}\text { TaT National Park } \\
\text { Cote d'Ivoire }\end{array}$ & Chimpanzee & $\begin{array}{l}\mathrm{pBCXO1} \\
\mathrm{pBCXO2}\end{array}$ & $\begin{array}{l}\text { Weakness, } \\
\text { vomiting, sudden } \\
\text { death }\end{array}$ & Often fatal & $\begin{array}{l}\text { Leendertz et al., } \\
\text { 2004; Klee et al., } \\
2006 \text {; Klee et al., } \\
2010\end{array}$ \\
\hline $\begin{array}{l}\text { B. cereus } \\
\text { JF3964 }\end{array}$ & Koza, Cameroon & Bovine & $\begin{array}{l}\mathrm{pBCXO1} \\
\mathrm{pBCXO2}\end{array}$ & $\begin{array}{l}\text { High fever, potential } \\
\text { bleeding from } \\
\text { mucous } \\
\text { membranes (e.g., } \\
\text { nose), sudden } \\
\text { death }\end{array}$ & Often fatal & Pilo et al., 2011 \\
\hline $\begin{array}{l}\text { B. cereus } \\
\text { BC-AK }\end{array}$ & China & Kangaroo & $\begin{array}{l}\mathrm{pBCXO1} \\
\mathrm{pBCXO2}\end{array}$ & Unknown & Unknown & Dupke et al., 2019 \\
\hline
\end{tabular}

Bcbva, Bacillus cereus biovar anthracis.

adenylate cyclase, increasing the concentration of cAMP inside the cell. This causes an osmotic imbalance, which interferes with cell signaling pathways and renders white blood cells ineffective but is not cytotoxic (Leppla, 1982).

In $B$. anthracis, the tripartite toxin is encoded by genes pagA (PA), lef (LF) and cya (EF) on the 181,677 bp plasmid, pXO1
(Okinaka et al., 1999). Bcbva strains harbor a similar sized plasmid, pBCXO1 (181,907 bp in the CI strain), which share 99$100 \%$ identity with pXO1 and encodes the genes for the toxins (Klee et al., 2010). In atypical strain G9241, the pBCXO1 plasmid is larger at $190,861 \mathrm{bp}$ and shares $99.6 \%$ identity with pXO1 (Hoffmaster et al., 2004; Klee et al., 2010). Presumably, expression 
TABLE 2 | B. cereus G9241 virulence in different mammalian models of infection.

\begin{tabular}{|c|c|c|c|c|c|}
\hline Model & Route of infection & Dose (cfu) & $\mathrm{LD}_{50}$ (cfu) & Notes & Study \\
\hline \multirow[t]{9}{*}{$\mathrm{A} / \mathrm{J}$ mice $^{1}$} & Intraperitoneal & $1 \times 10^{4}$ & Not measured & $\begin{array}{l}100 \% \text { lethality at } \sim 116 \mathrm{~h} \text { post inoculation } \\
\text { Comparative challenge with } B \text {. anthracis Sterne: } \\
100 \% \text { lethality after } \sim 74 \mathrm{~h} \text { post inoculation } \\
\text { End of study: } 5 \text { days post inoculation }\end{array}$ & Hoffmaster et al., 2004 \\
\hline & & $1 \times 10^{6}$ & Not measured & $\begin{array}{l}100 \% \text { lethality at } \sim 44 \mathrm{~h} \text { post inoculation } \\
\text { Comparative challenge with } B \text {. anthracis Sterne: } \\
100 \% \text { lethality at } \sim 52 \mathrm{~h} \text { post inoculation } \\
\text { End of study: } 5 \text { days post inoculation }\end{array}$ & \\
\hline & & $1 \times 10^{2}-1 \times 10^{5}$ & 381 & $\begin{array}{l}100 \% \text { lethality at doses of } 10^{4} \text { and } 10^{5} \mathrm{cfu} \\
\text { End of study: } 14 \text { days post inoculation }\end{array}$ & Oh et al., 2011 \\
\hline & Subcutaneous & $10^{3}-10^{6}$ & $1.3 \times 10^{3}$ & $\begin{array}{l}\text { MTTD } 3 \text { days at } 10^{5} \text { cfu dose } \\
\text { End of study: } 14 \text { days post inoculation }\end{array}$ & Wilson et al., 2011 \\
\hline & & & 7 & $\begin{array}{l}\text { MTTD } 3.5 \text { days at } 10^{2} \text { cfu dose } \\
\text { End of study: } 14 \text { days post inoculation }\end{array}$ & Scarff et al., 2016 \\
\hline & & & 10 & End of study: 14 days post inoculation & Seldina et al., 2018 \\
\hline & Intranasal & $10^{5}-10^{7}$ & $3.2 \times 10^{5}$ & $\begin{array}{l}\text { MTTD } 3 \text { days at } 10^{6} \text { cfu dose } \\
\text { End of study: } 14 \text { days post inoculation }\end{array}$ & Wilson et al., 2011 \\
\hline & & & $3.0 \times 10^{3}$ & $\begin{array}{l}\text { MTTD } 4 \text { days at } 10^{4} \text { cfu dose } \\
\text { End of study: } 14 \text { days post inoculation }\end{array}$ & Scarff et al., 2016 \\
\hline & & & $3.0 \times 10^{3}$ & End of study: 14 days post inoculation & Seldina et al., 2018 \\
\hline \multirow[t]{10}{*}{ C57BL/6 mice ${ }^{2}$} & Intraperitoneal & $1.0 \times 10^{2}-1 \times 10^{5}$ & 2,710 & $\begin{array}{l}100 \% \text { lethality at a dose of } 10^{5} \mathrm{cfu} \\
\text { End of study: } 14 \text { days post inoculation }\end{array}$ & Oh et al., 2011 \\
\hline & & $1.0 \times 10^{5}$ & Not measured & $\begin{array}{l}100 \% \text { lethality within } 4 \text { days post inoculation } \\
\text { End of study: } 14 \text { days post inoculation }\end{array}$ & Oh et al., 2013 \\
\hline & & & Not measured & $\begin{array}{l}\text { MTTD } 48.5 \mathrm{~h} \\
\text { End of study: } 14 \text { days post inoculation }\end{array}$ & Wang et al., 2013 \\
\hline & Subcutaneous & $10^{3}-10^{6}$ & $5.0 \times 10^{3}$ & $\begin{array}{l}\text { MTTD } 3 \text { days at } 10^{5} \text { cfu dose } \\
\text { End of study: } 14 \text { days post inoculation }\end{array}$ & Wilson et al., 2011 \\
\hline & & & 44 & $\begin{array}{l}\text { MTTD } 6 \text { days at } 10^{2} \text { cfu dose } \\
\text { End of study: } 14 \text { days post inoculation }\end{array}$ & Scarff et al., 2016 \\
\hline & & & 40 & End of study: 14 days post inoculation & Seldina et al., 2018 \\
\hline & Intranasal & $10^{5}-10^{7}$ & $6.3 \times 10^{5}$ & $\begin{array}{l}\text { MTTD } 3.5 \text { days at } 10^{7} \text { cfu dose } \\
\text { End of study: } 14 \text { days post inoculation }\end{array}$ & Wilson et al., 2011 \\
\hline & & & $4.0 \times 10^{5}$ & $\begin{array}{l}\text { MTTD } 3 \text { days at } 10^{7} \text { cfu dose } \\
\text { End of study: } 14 \text { days post inoculation }\end{array}$ & Scarff et al., 2016 \\
\hline & & & $4.0 \times 10^{5}$ & End of study: 14 days post inoculation & Seldina et al., 2018 \\
\hline & Aerosol & $1.0 \times 10^{8}-2.0 \times 10^{10}$ & $1.1 \times 10^{4}$ & $\begin{array}{l}100 \% \text { lethality at dose of } 2.3 \times 10^{5} \mathrm{cfu} \\
\text { End of study: } 14 \text { days post inoculation }\end{array}$ & Oh et al., 2013 \\
\hline
\end{tabular}


of these genes results in production of toxin components homologous to those found in $B$. anthracis, unless significant post-translational modification occurs. In one study, Marston et al. (2016) were able to detect LF, LF-neutralizing activity and anti-PA antibodies in the serum of a patient convalescing from cutaneous anthrax-like disease caused by an atypical $B$. cereus strain. Anti-LF and anti-PA Western blots also confirmed their presence in Bcbva strains (Brézillon et al., 2015). These data, coupled with the characteristic presentation of the disease [for example, formation of a black eschar (Marston et al., 2016)] suggests the anthrax toxins produced by $B$. cereus are not significantly different from those produced by $B$. anthracis.

\section{Extracellular Capsule}

The second component required for full virulence is an extracellular capsule. In $B$. anthracis, a poly- $\gamma$-D-glutamic acid (polyglutamate) capsule is produced which prevents opsonization and phagocytosis of vulnerable vegetative bacilli (Scorpio et al., 2007, 2010).

As summarized in Table 3, there are several capsules that can potentially be expressed by atypical $B$. cereus and Bcbva strains dependent on the plasmids harbored. The first is a hyaluronic acid (HA) capsule, which may be expressed by atypical $B$. cereus and Bcbva strains. Like the anthrax tripartite toxin, genes encoding the HA capsule are harbored on the pXO1 (and pBCXO1) plasmid, encoded by the has $A C B$ operon. In $B$. anthracis, the capsule is not expressed due to a frameshift mutation in hasA, which results in premature termination of translation (Okinaka et al., 1999). However, the pBCXO1 plasmid may possess a non-mutated hasA gene, enabling the HA capsule to be expressed. Functional genes for the has ACB operon have been identified in atypical B. cereus strains 03BB87, 03BB102, FL2013, LA2007, G9241, and Elc2 and in five Bcbva strains, including CA and CI (Pena-Gonzalez et al., 2018). Expression of this capsule was observed in atypical B. cereus strain G9241 and Bcbva strains CA and CI (Hoffmaster et al., 2004; Brézillon et al., 2015).

In addition to the HA capsule, several atypical strains are capable of producing a unique exopolysaccharide (Bps) capsule. It is encoded by a nine gene operon, bpsX-H, on plasmid pBC210 (formerly pBC218), which is not found in B. anthracis or Bcbva strains (Table 3). Homologs of the genes are found in other species, including Streptococcus pyogenes, allowing gene functions to be putatively assigned (Oh et al., 2011). Atypical B. cereus strains G9241, G9898, 03BB87, and LA2009 encode the Bps capsule and have been associated with fatal and nonfatal inhalational anthrax-like disease in humans (Miller et al., 1997; Hoffmaster et al., 2004; Sue et al., 2006). Additionally, strain FL2013 has a partial sequence for the pBC210 plasmid, but does not harbor the bpsX-H operon (Gee et al., 2014; Marston et al., 2016). The Bcbva strains do not possess the pBC210 plasmid; however, they do harbor the $\mathrm{pBCXO} 2$ plasmid that is highly similar to $\mathrm{pXO} 2$ from $B$. anthracis (Table 3). It encodes the cap $B C A$ genes, for expression of the polyglutamate capsule. This unusual proteinaceous capsule is required for full virulence in B. anthracis; for example, pXO2 is cured from the Sterne strain and is sufficiently attenuated in animals to be 
used as a live vaccine for livestock (Uchida et al., 1985; Cataldi et al., 2000). The Bcbva strains therefore, express the anthrax toxins and $\mathrm{HA}$ capsule from $\mathrm{pBCXO1}$ and the polyglutamate capsule from $\mathrm{pBCXO} 2$. In addition to the Bcbva strains, one atypical strain isolated in the United States, B. cereus 03BB102, was found to possess the cap genes although there was no evidence to suggest the polyglutamate capsule is expressed (Hoffmaster et al., 2006). It is an unusual strain as it harbors partial sequences for $\mathrm{pBCXO} 1$ and $\mathrm{pBCXO} 2$ as well as additional plasmid pBC210 (Table 3; Hoffmaster et al., 2006; PenaGonzalez et al., 2018). Two further strains, B. cereus JF3964 and $B$. cereus $\mathrm{BC}-\mathrm{AK}$, isolated in China, also possess cap genes on a pBCXO2 plasmid (Pilo et al., 2011; Dupke et al., 2019; Table 3). However, these strains have not yet been shown to express the polyglutamate capsule.

Atypical B. cereus and Bcbva strains may express the HA capsule. When visualized by microscopy, the HA capsule can be observed forming a large protective layer around vegetative bacilli in strains of both atypical $B$. cereus and Bcbva (Brézillon et al., 2015; Scarff et al., 2018). In mouse models, for both atypical B. cereus and Bcbva strains, virulence was maintained with sole expression of the HA capsule via the inhalational route, with mild attenuation via the cutaneous route (Brézillon et al., 2015; Scarff et al., 2018). Atypical B. cereus strains with a missing or incomplete $\mathrm{pBC} 210$ plasmid have been associated with fatal inhalational anthrax-like disease (03BB102) and characteristic cutaneous anthrax-like disease (FL2013) in humans (Hoffmaster et al., 2006; Marston et al., 2016). These data suggest that encapsulation with HA alone (along with anthrax toxin expression) is sufficient to enable $B$. cereus to cause anthrax-like disease in mammals. Compared to the HA capsule, the Bps capsule is a less important virulence factor. When visualized by microscopy, the exopolysaccharide encapsulates the bacilli in a much thinner layer than the HA capsule (Oh et al., 2011; Scarff et al., 2018). In mouse models, deletion of the HA capsule from B. cereus G9241 resulted in an increased $L_{50}$ via subcutaneous and inhalational routes (Scarff et al., 2018) and increased time to death and reduction of mortality (Oh et al., 2011) despite production of the Bps capsule suggesting a level of attenuation. There are no known cases of anthrax-like disease in humans or other mammals caused by anthrax-toxin expressing B. cereus strains producing only the Bps capsule. In contrast, Bcbva strains with a deletion of only the HA capsule, retaining the polyglutamate capsule, caused no reduction in virulence (Brézillon et al., 2015).

\section{Certhrax Toxin and Other Virulence Factors}

In addition to capsules and anthrax toxins, the emerging $B$. cereus strains possess other virulence factors not found in $B$. anthracis. For example, the pBC210 plasmid in B. cereus G9241 (and related atypical strains) encodes a mono-ADPribosyltransferase (mART) that has been designated certhrax toxin (Fieldhouse et al., 2010; Visschedyk et al., 2012; Simon et al., 2013; Simon and Barbieri, 2014; Seldina et al., 2018).
It shares $51 \%$ structural similarity with $B$. anthracis LF. Each protein contains a PA binding domain that facilitates entry into the host cell. However, whilst the certhrax derives its toxicity from a mART domain, this is inactive in LF which possesses a functional metalloprotease domain (Figure 3; Visschedyk et al., 2012; Simon et al., 2013). Therefore, the two proteins cause toxicity via different mechanisms. The target for certhrax is vinculin which is part of the cytoskeletal complex and is involved in focal adhesion (Simon and Barbieri, 2014). Certhrax demonstrated 60x greater toxicity against RAW264.7 cells than LF (Simon and Barbieri, 2014). However, a recent study of LF, certhrax and $\mathrm{LF} /$ certhrax deletion mutants virulence in $\mathrm{AJ}$ and $\mathrm{C} 57 \mathrm{BL} / 6$ mice demonstrated certhrax plays a minimal role in the virulence of $B$. cereus G9241 and may even cause attenuation (Seldina et al., 2018).

In addition to the certhrax toxin, atypical strains that possess the pBC210 plasmid also harbor PA and LF orthologs, designated protective antigen 2 (PA2) and CerADPr respectively (Oh et al., 2013; Seldina et al., 2018). The PA homolog in atypical B. cereus strains is highly similar to the $\mathrm{PA}$ in $B$. anthracis, with each domain sharing between 99 and 100\% amino acid identity. In contrast, the PA2 domains share between 45 and $70 \%$ amino acid identity to PA from B. anthracis (Oh et al., 2013). Furthermore, PA2 is a weak virulence factor in mouse models compared to $\mathrm{PA}$ and is a poor antigen for immunization (Oh et al., 2013; Seldina et al., 2018). Whilst currently these virulence factors appear inconsequential, further structural or functional changes may enhance their significance as virulence factors in atypical $B$. cereus strains.

Another structural feature is the S-layer (or surface layer) which can play a role in virulence. In B. cereus G9241, many S-layer proteins share homology with those found in B. anthracis and its impairment can result in mild reduction in virulence (Wang et al., 2013).

s Other virulence factors, such as hemolysis, motility and penicillin resistance are differentially expressed by atypical $B$. cereus and Bcbva strains depending upon genomic variation (see next section) (Table 4). Further genetic elements unique to different $B$. cereus strains may encode unidentified virulence factors. Functions for genomic islands I-VI in Bcbva strains, plasmid pCI-14 in Bcbva CI and pBFH_1 phagemid in B. cereus G9241 and related strains have not yet been elucidated (Table 3; Klee et al., 2010; Johnson et al., 2015; Antonation et al., 2016). $B$. cereus $\mathrm{BC}-\mathrm{AK}$ also possesses an additional plasmid, $\mathrm{pBC} 244$, which appears unique to the strain and is of unknown function (Dupke et al., 2019; Table 3).

\section{GENETIC REGULATION}

Two genomic elements in $B$. anthracis that regulate virulence factor expression are AtxA and the PlcR-PapR regulon. AtxA is a global regulator of virulence factors and its complex matrix of interactions has been reviewed (Fouet, 2010). Its best-known function is to upregulate the expression of tripartite anthrax toxin (PA, LF and EF). AtxA is active in B. anthracis strains 
TABLE 3 | Plasmid possession, virulence factor expression and ability to cause anthrax-like disease for different strains of $B$. anthracis and B. cereus.

\begin{tabular}{|c|c|c|c|c|c|c|c|}
\hline Organism & pXO1 / pBCXO1 & $\begin{array}{c}\text { Genbank accession } \\
\text { number/size (bp) }\end{array}$ & pXO2 / pBCXO2 & \begin{tabular}{|c|}
$\begin{array}{c}\text { Genbank accession } \\
\text { number/size (bp) }\end{array}$ \\
\end{tabular} & Additional plasmids & $\begin{array}{l}\text { Genbank accession } \\
\text { numbers/sizes (bp) }\end{array}$ & $\begin{array}{c}\text { Causes anthrax(- } \\
\text { like) disease }\end{array}$ \\
\hline $\begin{array}{c}\text { B. anthracis } \\
\text { Ames }\end{array}$ & PA, EF, LF toxins only & $\begin{array}{l}\text { AE017336 } \\
181,677 \text { bp }\end{array}$ & polyglutamate capsule & $\begin{array}{l}\text { AE017335 } \\
94,830 \text { bp }\end{array}$ & None & - & Yes \\
\hline $\begin{array}{c}\text { B. anthracis } \\
\text { Sterne }\end{array}$ & PA, EF, LF toxins only & $\begin{array}{l}\text { CP009540 } \\
181,624 \mathrm{bp}\end{array}$ & None & - & None & - & No \\
\hline $\begin{array}{l}\text { B. cereus } \\
\text { wild type } \\
\end{array}$ & None & - & None & - & Yes - various & Various & No \\
\hline $\begin{array}{l}\text { B. cereus } \\
\text { G9241 }\end{array}$ & $\begin{array}{l}\mathrm{PA}, \mathrm{EF}, \mathrm{LF} \text { toxins } \\
\text { hyaluronic acid capsule }\end{array}$ & $\begin{array}{l}\text { CP009592 } \\
190,860 \text { bp }\end{array}$ & None & - & $\begin{array}{c}\text { pBC210 } \\
\begin{array}{c}\text { polysaccharide } \\
\text { capsule }\end{array}\end{array}$ & $\begin{array}{|cc|}\text { pBC210 } & \text { pBFH_1 } \\
\text { CP009591 } & \text { CP009589 } \\
209,255 \text { bp } & 52,166 \text { bp } \\
\end{array}$ & Yes \\
\hline $\begin{array}{l}\text { B. cereus } \\
\text { 03BB87 }\end{array}$ & $\begin{array}{l}P A, E F, L F \text { toxins } \\
\text { hyaluronic acid capsule }{ }^{1}\end{array}$ & $\begin{array}{l}\text { CP009940 } \\
209,381 \text { bp }\end{array}$ & None & - & $\begin{array}{l}\text { CN Identical to } \mathrm{pBFH} \text { _1 } \\
\text { Function unknown }\end{array}$ & \begin{tabular}{cc|}
$\mathrm{pBC210}$ & $\mathrm{pBCN}$ \\
Putative & $\mathrm{CP009939}$ \\
& $52,166 \mathrm{bp}$
\end{tabular} & Yes \\
\hline $\begin{array}{l}\text { B. cereus } \\
03 \mathrm{BB} 102\end{array}$ & $\begin{array}{l}\text { PA, EF, LF toxins } \\
\text { hyaluronic acid capsule }\end{array}$ & $\begin{array}{l}\text { CP009317 } \\
179,680 \mathrm{bp}\end{array}$ & $\left(\begin{array}{c}\text { polyglutamate capsule } \\
\mathrm{pBCXO2} \text { genes present, } \\
\text { expression not detected }\end{array}\right.$ & $\begin{array}{c}\text { Putative; sequence } \\
\text { not available }\end{array}$ & & - & Yes \\
\hline $\begin{array}{l}\text { B. cereus } \\
\text { Elc2 }\end{array}$ & $\begin{array}{l}\text { PA, EF, LF toxins } \\
\text { hyaluronic acid capsule }\end{array}$ & $\begin{array}{l}\text { Sequence not } \\
\text { available }\end{array}$ & None & - & None identified & - & Yes \\
\hline $\begin{array}{l}\text { B. cereus } \\
\mathrm{FL} 2013 \\
\end{array}$ & $\begin{array}{l}\text { PA, EF, LF toxins } \\
\text { hyaluronic acid capsule }\end{array}$ & $\begin{array}{c}\text { Shotgun } \\
\text { sequences only } \\
\text { JHQNO0000000 }\end{array}$ & None & - & pBC210 $\begin{array}{c}\text { Partial sequence } \\
108,352 \mathrm{bp}\end{array}$ pBFH_1 $_{\sim}^{\text {Partial sequence }} \sim 48 \mathrm{kbp}$ & $\begin{array}{c}\text { Shotgun } \\
\text { sequences only } \\
\text { JHQNO0000000 }\end{array}$ & Yes \\
\hline $\begin{array}{l}\text { B. cereus } \\
\text { LA2007 }\end{array}$ & $\begin{array}{l}\text { PA, EF, LF toxins } \\
\text { hyaluronic acid capsule }\end{array}$ & $\begin{array}{c}\text { Shotgun } \\
\text { sequences only } \\
\text { MUBB000000000 }\end{array}$ & None & - & $\begin{array}{c}\text { 0) Polysaccharide } \\
\text { capsule }^{1}\end{array}$ & $\begin{array}{c}\text { Shotgun } \\
\text { sequences only } \\
\text { MUBB00000000 }\end{array}$ & Yes \\
\hline $\begin{array}{l}\text { B. cereus } \\
\text { G9898 }\end{array}$ & $\begin{array}{l}\mathrm{PA}, \mathrm{EF}, \mathrm{LF} \text { toxins } \\
\text { hyaluronic acid capsule }\end{array}$ & $\begin{array}{l}\text { Sequence not } \\
\text { available }\end{array}$ & None & - & 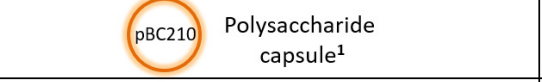 & $\begin{array}{l}\text { Putative; sequence } \\
\text { not available }\end{array}$ & Yes \\
\hline $\begin{array}{c}\text { Bcbva } \\
\text { CA }\end{array}$ & $\begin{array}{l}\mathrm{PA}, \mathrm{EF}, \mathrm{LF} \text { toxins } \\
\text { hyaluronic acid capsule }\end{array}$ & $\begin{array}{l}\text { Sequence not } \\
\text { available }\end{array}$ & polyglutamate capsule & $\begin{array}{l}\text { Sequence not } \\
\text { available }\end{array}$ & None & - & Yes \\
\hline $\begin{array}{c}\text { Bcbva } \\
\mathrm{Cl}\end{array}$ & $\begin{array}{l}\text { PA, EF, LF toxins } \\
\text { hyaluronic acid capsule }\end{array}$ & $\begin{array}{l}\text { CP001747 } \\
181,907 \mathrm{bp}\end{array}$ & polyglutamate capsule & $\begin{array}{l}\text { CP001748 } \\
94,469 \text { bp }\end{array}$ & $\begin{array}{l}\text { 4) Sometimes present } \\
\text { Function unknown }\end{array}$ & $\begin{array}{l}\text { CP001749 } \\
14,219 \text { bp }\end{array}$ & Yes \\
\hline $\begin{array}{l}\text { B. cereus } \\
\text { JF3964 }\end{array}$ & $\begin{array}{l}\text { PA, EF, LF toxins } \\
\text { hyaluronic acid capsule }\end{array}$ & $\begin{array}{l}\text { Sequence not } \\
\text { available }\end{array}$ & polyglutamate capsule ${ }^{1}$ & $\begin{array}{l}\text { Sequence not } \\
\text { available }\end{array}$ & None identified & - & Yes \\
\hline $\begin{array}{l}\text { B. cereus } \\
\text { BC-AK }\end{array}$ & $\begin{array}{l}\text { PA, EF, LF toxins } \\
\text { hyaluronic acid capsule }{ }^{1}\end{array}$ & $\begin{array}{l}\text { CP020940 } \\
168,378 \mathrm{bp}\end{array}$ & polyglutamate capsule ${ }^{1}$ & $\begin{array}{l}\text { CP020941 } \\
88,621 \text { bp }\end{array}$ & $\begin{array}{l}\text { Function } \\
\text { unknown }\end{array}$ & $\mid \begin{array}{cc}\mathrm{pBC} 244 & \mathrm{pBC} 52 \\
\mathrm{CP} 020938 & \mathrm{eP0209939} \\
244,929 \mathrm{bp} & 52,693 \mathrm{bp}\end{array}$ & Yes \\
\hline
\end{tabular}

Bcbva, Bacillus cereus biovar anthracis; 1, genes shown to be present by PCR or sequencing, expression unverified; 2, genes may or may not be present, sequence unknown. 
TABLE 4 | Genetic and phenotypic differences between strains of B. anthracis and B. cereus.

\begin{tabular}{|c|c|c|c|c|c|c|c|c|c|}
\hline Organism & $\begin{array}{l}\text { AtxA regulator } \\
\text { (anthrax toxins) }\end{array}$ & $\begin{array}{l}\text { PIcR-PapR } \\
\text { regulon } \\
\text { (secondary } \\
\text { factors) }\end{array}$ & $\begin{array}{l}\text { has } A C B \text { operon } \\
\text { (HA* capsule) }\end{array}$ & Hemolytic & Motile & $\begin{array}{l}\text { y-phage } \\
\text { resistant }\end{array}$ & $\begin{array}{l}\text { Penicillin } \\
\text { resistant }\end{array}$ & $\begin{array}{l}\text { Causes anthrax } \\
\text { (-like) disease }\end{array}$ & References \\
\hline $\begin{array}{c}\text { B. anthracis } \\
\text { Ames }\end{array}$ & Functional & $\begin{array}{l}\text { Nonsense mutation } \\
\text { Non-functional }\end{array}$ & $\begin{array}{l}\text { Frameshift mutation } \\
\text { Non-functional }\end{array}$ & No & No & No & No & Yes & $\begin{array}{l}\text { Read et al., 2003; } \\
\text { Hoffmaster et al., } \\
\text { 2006; Kolstø et al., } \\
2009\end{array}$ \\
\hline $\begin{array}{l}\text { B. anthracis } \\
\text { Sterne }\end{array}$ & Functional & $\begin{array}{l}\text { Nonsense mutation } \\
\text { Non-functional }\end{array}$ & $\begin{array}{l}\text { Frameshift mutation } \\
\text { Non-functional }\end{array}$ & No & No & No & No & No & $\begin{array}{l}\text { Cataldi et al., 2000; } \\
\text { Kolstø et al., 2009 }\end{array}$ \\
\hline $\begin{array}{l}\text { B. cereus } \\
\text { wild type }\end{array}$ & None & Functional & None & Yes & Yes & Yes & Yes & No & Kolstø et al., 2009 \\
\hline $\begin{array}{l}\text { B. cereus } \\
\text { G9241 }\end{array}$ & Functional & Functional & Functional & Yes & Yes & Yes & Yes & Yes & $\begin{array}{l}\text { Hoffmaster et al., } \\
2004,2006\end{array}$ \\
\hline $\begin{array}{c}\text { B. cereus } \\
03 \text { BB887 }\end{array}$ & Functional & Functional & Functional & Yes & Yes & Yes & Not tested & Yes & $\begin{array}{l}\text { Hoffmaster et al., } \\
2006\end{array}$ \\
\hline $\begin{array}{l}\text { B. cereus } \\
\text { 03BB102 }\end{array}$ & Functional & Functional & Functional & Yes & Yes & Yes & Not tested & Yes & $\begin{array}{l}\text { Hoffmaster et al., } \\
2006\end{array}$ \\
\hline $\begin{array}{l}\text { B. cereus } \\
\text { Elc2 }\end{array}$ & Functional & Functional & Functional & Yes & Yes & Not tested & Yes & Yes & Wright et al., 2011 \\
\hline $\begin{array}{l}\text { B. cereus } \\
\text { FL2013 }\end{array}$ & Functional & Functional & Functional & Yes & Not tested & Yes & Yes & Yes & $\begin{array}{l}\text { Marston et al., } \\
2016\end{array}$ \\
\hline $\begin{array}{l}\text { B. cereus } \\
\text { LA2007 }\end{array}$ & Functional & Functional & Functional & Not tested & Not tested & Not tested & Not tested & Yes & $\begin{array}{l}\text { Pena-Gonzalez } \\
\text { et al., } 2017\end{array}$ \\
\hline $\begin{array}{l}\text { B. cereus } \\
\text { G9898 }\end{array}$ & Functional & $\begin{array}{l}\text { Sequence } \\
\text { unavailable }\end{array}$ & $\begin{array}{l}\text { Sequence } \\
\text { unavailable }\end{array}$ & Yes & Not tested & Not tested & Yes & Yes & $\begin{array}{l}\text { Miller et al., 1997; } \\
\text { Sue et al., } 2006\end{array}$ \\
\hline $\begin{array}{c}\text { Bcbva } \\
\text { CA }\end{array}$ & Functional & $\begin{array}{l}\text { Frameshift mutation } \\
\text { Non-functional }\end{array}$ & Functional & No & Yes & Yes & Yes & Yes & $\begin{array}{l}\text { Klee et al., 2006; } \\
\text { Antonation et al., } \\
2016\end{array}$ \\
\hline $\begin{array}{c}\text { Bcbva } \\
\mathrm{Cl}\end{array}$ & Functional & $\begin{array}{l}\text { Frameshift mutation } \\
\text { Non-functional }\end{array}$ & Functional & No & Yes & Yes & No & Yes & $\begin{array}{l}\text { Klee et al., 2006; } \\
\text { Antonation et al., } \\
2016\end{array}$ \\
\hline $\begin{array}{c}\text { B. cereus } \\
\mathrm{JF} 3964 \\
\end{array}$ & Functional & $\begin{array}{l}\text { Sequence } \\
\text { unavailable }\end{array}$ & $\begin{array}{l}\text { Sequence } \\
\text { unavailable }\end{array}$ & No & Not tested & Yes & Yes & Yes & Pilo et al., 2011 \\
\hline $\begin{array}{l}\text { B. cereus } \\
\text { BC-AK }\end{array}$ & Functional & Functional & Functional & Not tested & Not tested & Not tested & Not tested & Yes & Dupke et al., 2019 \\
\hline
\end{tabular}

Bcbva, B. cereus biovar anthracis; Functional, genes of the operon do not contatin inactivating mutations, this does not indicate whether or not they are successfully expressed. 


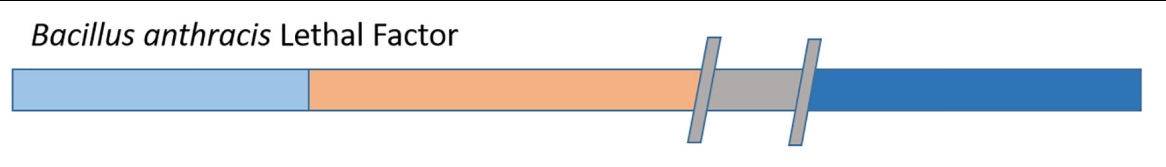

\section{Bacillus cereus Certhrax}

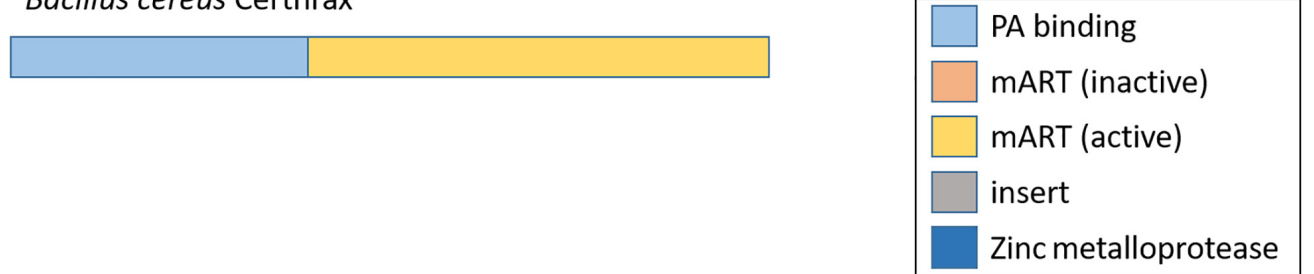

FIGURE 3 | Domain organization of lethal factor from B. anthracis and certhrax from B. cereus G9241. Each contains a protective antigen (PA) binding domain and mono-ADP-ribosyltransferase (mART) domain. This is inactivated in lethal factor by an insertion. Lethal factor derives its toxicity from a metalloprotease domainwhich is absent in certhrax.

and all B. cereus strains that cause anthrax-like disease, encoded on $\mathrm{pXO} 1$ and $\mathrm{pBCXO} 1$ respectively. In addition to the toxins, AtxA also upregulates the functional has $A C B$ operon in atypical $B$. cereus and Bcbva strains for HA capsule expression (Brézillon et al., 2015; Scarff et al., 2016).

At least 45 genes are known to be under the control of the PlcR-PapR regulon, regulating a number of virulence factors such as enterotoxins, hemolysins and various proteases (Agaisse et al., 1999; Gohar et al., 2008). In B. anthracis, a nonsense mutation in the plcR gene disables the regulon and $B$. anthracis is typically non-hemolytic and does not produce enterotoxin (Agaisse et al., 1999; Mignot et al., 2001). It is proposed that the inactivated PlcR-PapR regulon and absence of accessory virulence factor expression contributes to the ability of $B$. anthracis to evade the mammalian immune system, establish an infection and ultimately cause disease. All other species in the $B$. cereus s. $l$. group, including $B$. cereus, possess a functional PlcR-PapR regulon. Within these species, approximately $1 \%$ of subspecies have a non-functional mutation (Slamti et al., 2004). Wild type $B$. cereus is therefore phenotypically distinct from B. anthracis.

In the atypical $B$. cereus strains, the PlcR-PapR regulon is active, enabling the expression of accessory virulence factors. Despite this, these strains are capable of causing anthraxlike disease. The mechanisms for this are poorly understood and are an area of ongoing research. A functioning PlcRPapR regulon may also adversely affect sporulation efficacy; a study by Mignot et al. (2001) demonstrated a reduced ability for sporulation in $B$. anthracis with an activated PlcRPapR regulon, suggesting conflict with a functioning gene for AtxA. However, this was contradicted by a later study, which showed rapid and complete sporulation is achievable in B. anthracis with an activated PlcR-PapR regulon (Sastalla et al., 2010). The reason for this discrepancy has not been elucidated and may be due to experimental differences (for example, the first study used homologous recombination to restore a functioning $p l c R$ gene on the chromosome, whereas the second study produced PlcR-PapR from a plasmid). However, there is evidence to suggest AtxA and $\mathrm{PlcR}$ are active under different growth conditions (Passalacqua et al., 2009). The full understanding of these inconsistencies and the precise mechanisms of both genetic regulatory systems could be an important area for future research. The atypical B. cereus strains also possess a second AtxA (designated AtxA2) on the pBC210 plasmid. It shares $79 \%$ identity with AtxA (Scarff et al., 2016). AtxA2 is capable of upregulating Bps capsule production and, to a lesser extent, HA capsule and tripartite toxin production. Deletion of AtxA2 results in a reduction in virulence in mouse models and deletion of both orthologs results in a mutant that is unable to sporulate (Scarff et al., 2016).

For Bcbva strains, the PlcR-PapR regulon has been inactivated by a frameshift mutation, which is different than the nonsense mutation in B. anthracis and has therefore evolved independently (Klee et al., 2010; Antonation et al., 2016). Phenotypically, the Bcbva strains are consistent with an inactive $\mathrm{PlcR}-\mathrm{PapR}$ regulon (such as non-hemolytic and no phospholipase $\mathrm{C}$ activity).

Both atypical $B$. cereus and Bcbva strains are motile, whereas $B$. anthracis is characteristically immotile. This phenotype is caused by mutations in flagella genes that are functional in the $B$. cereus strains (Klee et al., 2010). One outlier is Bcbva strain DRC, which has an early stop codon in the fliP gene, rendering it immotile (Antonation et al., 2016). Whilst no motility genes were identified as under the control of the PlcR-PapR regulon by Gohar et al. (2008), an earlier study found PlcR binding sites in the promotor regions of some flagella genes (Ivanova et al., 2003). Further investigation is required to determine whether the PlcR-PapR regulon plays a role in the motility of these bacteria.

\section{PREVENTION AND TREATMENT}

Comprehensive advice on the prevention and treatment of anthrax can be found from the European Medicines Agency, Health Protection Agency and Centers for Disease Control and Prevention (European Medicines Agency/ Committee for Human Medicinal Products (EMA/CHMP), 2014; Health 
Protection Agency [HPA], 2017; Centres for Disease Control and Prevention (CDC), 2015).

Any person thought to have been exposed to $B$. anthracis can be administered a post-exposure prophylactic course of oral antibiotics, usually ciprofloxacin or doxycycline. B. cereus is not known to be resistant to these antibiotics. Some strains of Bcbva showed intermediate sensitivity (mild resistance) to amoxicillin-clavulanic acid (Klee et al., 2006) and resistance to $\beta$-lactam antibiotics such as penicillin is commonly observed in $B$. cereus strains found in the food chain (Owusu-Kwarteng et al., 2017; Shawish and Tarabees, 2017). In severe cases of anthrax, or in patients with allergies to quinolones, ampicillin may be prescribed as a secondary drug. Therefore, correct identification of the causative bacteria could be important to ensure the most effective therapy is provided. However, only doxycycline and ciprofloxacin are licensed by FDA for use with inhalational anthrax (US Food and Drug Administration (FDA), 2008, 2016).

In the event of patients presenting with suspected anthrax, they will be treated according to the severity of their symptoms. Treatment could range from a course of oral antibiotics to intravenous antibiotic therapy, intensive care and surgery (for example, debridement in the case of injectional anthrax) as required.

\section{Vaccine}

Vaccines produced in the United Kingdom and United States (anthrax vaccine precipitated (AVP) and anthrax vaccine adsorbed (AVA) respectively) largely induce an antibody response to the PA and, to a lesser extent, LF (AVP and AVA) and EF (AVA only). As the toxins expressed by atypical B. anthracis and Bcbva strains are homologous to those produced by B. anthracis, it is hypothesized that these currently licensed vaccines will provide adequate protection against anthrax-like disease caused by B. cereus. Studies in C57BL/6 mice and Dunkin Hartley guinea pigs confirmed that vaccination with $\mathrm{PA}$ is sufficient to provide protective, though not sterilizing, immunity against $B$. cereus G9241 (Oh et al., 2013; Palmer et al., 2014). Furthermore, a formaldehyde-inactivated spore and PA preparation generated immunity to Bcbva strains in outbred mice (Brézillon et al., 2015). Whilst there are no data from humans or primates and neither the United Kingdom nor United States vaccines are licensed for use against atypical B. cereus and Bcbva strains, it is likely both vaccines generate protective immunity against these emerging pathogens. However, this presumes there are no post-translational modifications or further evolution within the emerging strains and that pathology is not caused by other mechanisms. For example, whilst expression of certhrax toxin and PA2 has been demonstrated to be insufficient to generate full virulence (Seldina et al., 2018), further evolution may enable the atypical $B$. cereus strains to evade the vaccine. This highlights the need for continuing research and monitoring into emerging microbial pathogens.

\section{Anti-toxin}

Anti-toxin antibodies may also be administered to a patient with inhalational anthrax. As with the vaccine, it is assumed that the anthrax toxins produced by $B$. cereus are homologous to those produced by $B$. anthracis and the treatment should be similarly effective. However, there is a wider debate ongoing as to whether anti-toxin therapy adds value to the treatment of anthrax disease (Vietri, 2018; Tournier et al., 2019).

\section{SUMMARY}

Classically, B. anthracis was considered the sole causative agent of anthrax disease in humans and mammals. However, in the past few decades, closely related strains of $B$. cereus have been identified that have obtained highly similar virulence plasmids and are capable of causing fatal anthrax-like disease. Two variants have emerged; atypical $B$. cereus strains that possess the pBCXO1 plasmid and Bcbva (B. cereus biovar anthracis) that possess both the pBCXO1 and pBCXO2 plasmids (Table 3). All of these strains produce the anthrax toxins and an extracellular capsule that enable them to cause anthrax-like disease. Atypical strains may produce a unique exopolysaccharide (Bps) capsule and Bcbva strains a polyglutamate capsule that is also expressed by B. anthracis. Additionally, both atypical and Bcbva strains may express a hyaluronic acid capsule that is encoded for but inactive in B. anthracis (Tables 3, 4).

Interestingly, the atypical strains have only been identified in the United States, whereas the Bcbva strains have been isolated in West African countries. Bcbva has caused widespread deaths in mammalian wildlife, including chimpanzees (Leendertz et al., 2004, 2006; Klee et al., 2006; Pilo et al., 2011; Antonation et al., 2016; Hoffmann et al., 2017; Zimmermann et al., 2017). To date, there have been no cases of anthrax-like disease recorded in humans caused by Bcbva. However, a recent study found serological evidence of human exposure to Bcbva in an endemic region of Côte d'Ivoire (Dupke et al., 2020). In contrast, the atypical $B$. cereus strains have been associated with fatal inhalational anthrax-like disease and characteristic cutaneous anthrax-like disease in humans. Despite all known human cases occurring in the United States, these incidents were separated geographically and temporally and involved several different strains, including those with the additional Bps capsule (such as G9241) and those without (such as FL2013) (Tables 1, 3; Hoffmaster et al., 2004, 2006; Avashia et al., 2007; Wright et al., 2011; Marston et al., 2016; Pena-Gonzalez et al., 2017). Therefore, it can be concluded that bacteria with a B. cereus chromosome are capable of causing anthrax-like disease if they are able to express the anthrax toxins and are encapsulated. There is also evidence for strains outside of these geographical areas; for example, Bcbva-like strain BC-AK was isolated from a kangaroo in China (Dupke et al., 2019). This suggests B. cereus capable of causing anthrax-like disease may already be distributed across the globe.

Fortunately, as the mechanism of pathogenicity is the same through production of tripartite anthrax toxin, it is highly likely that current anthrax vaccines will provide effective immunity against the atypical B. cereus and Bcbva strains (Oh et al., 2013; Palmer et al., 2014; Brézillon et al., 2015). The bacteria are also susceptible to frontline antibiotics, though administration of secondary $\beta$-lactamase antibiotics (such as penicillin) may have 
reduced efficacy due to inherent resistance in many $B$. cereus strains (Table 4; Klee et al., 2006).

Atypical B. cereus and Bcbva strains have diverse phenotypes and may retain other typical $B$. cereus characteristics such as motility, $\gamma$-phage resistance and production of secondary virulence factors (e.g., hemolysin) (Table 4). The apparent hybridity of these strains further demonstrates the close relatedness of the $B$. cereus $s$. $l$. group. The nomenclature applied to these strains is not well established and may be confusing. Here we propose "atypical strains" apply to those with a $B$. cereus chromosome and only the pBCXO1 plasmid, with "Bcbva" applied to those with a B. cereus chromosome and both the pBCXO1 and pBCXO2 plasmids. This could be extended to include $B$. cereus strains JF3964 and $\mathrm{BC}-\mathrm{AK}$ as they also harbor both plasmids, despite not belonging to the cluster described by Antonation et al. (2016). It is also unclear how B. cereus 03BB102 should be defined, with its partial plasmids. It is evident that these strains are more diverse than previously thought and Carroll et al. (2020) have proposed a novel taxonomy for renaming the $B$. cereus sensu lato group to reflect the genomic and phenotypic variety. If it becomes widely accepted that the

\section{REFERENCES}

Agaisse, H., Gominet, M., Okstad, O. A., Kolstø, A. B., and Lereclus, D. (1999). $\mathrm{PlcR}$ is a pleiotropic regulator of extracellular virulence factor gene expression in Bacillus thuringiensis. Mol. Microbiol. 32, 1043-1053. doi: 10.1046/j.13652958.1999.01419.x

Agata, N., Ohta, M., and Yokoyama, K. (2002). Production of Bacillus cereus emetic toxin (cereulide) in various foods. Int. J. Food Microbiol. 73, 23-27. doi: 10.1016/s0168-1605(01)00692-4

Antonation, K. S., Grützmacher, K., Dupke, S., Mabon, P., Zimmermann, F., Lankester, F., et al. (2016). Bacillus cereus biovar anthracis causing anthrax in Sub-Saharan Africa-chromosomal monophyly and broad geographic distribution. PLoS Negl. Trop. Dis. 10:e004923. doi: 10.1371/journal.pntd. 0004923

Antonini, J. M., Lewis, A. B., Roberts, J. R., and Whaley, D. A. (2003). Pulmonary effects of welding fumes: review of worker and experimental animal studies. Am. J. Ind. Med. 43, 350-360. doi: 10.1002/ajim.10194

Avashia, S. B., Riggins, W. S., Lindley, C., Hoffmaster, A., Drumgoole, R., Nekomoto, T., et al. (2007). Fatal pneumonia among metalworkers due to inhalation exposure to Bacillus cereus containing Bacillus anthracis toxin genes. Clin. Infect. Dis. 44, 414-416. doi: 10.1086/510429

Bazinet, A. L. (2017). Pan-genome and phylogeny of Bacillus cereus sensu lato. BMC Evol. Biol. 17:176. doi: 10.1186/s12862-017-1020-1

Bekemeyer, W. B., and Zimmerman, G. A. (1985). Life-threatening complications associated with Bacillus cereus pneumonia. Am. Rev. Respir. Dis. 131, 466-469.

Böhm, M. E., Huptas, C., Krey, V. M., and Scherer, S. (2015). Massive horizontal gene transfer, strictly vertical inheritance and ancient duplications differentially shape the evolution of Bacillus cereus enterotoxin operons $h b l$, cytK and nhe. BMC Evol. Biol. 15:246. doi: 10.1186/s12862-0150529-4

Brett, M. M., Hood, J., Brazier, J. S., Duerden, B. I., and Hahné, S. J. M. (2005). Soft tissue infections caused by spore-forming bacteria in injecting drug users in the United Kingdom. Epidemiol. Infect. 133, 575-582. doi: 10.1017/ s0950268805003845

Brézillon, C., Haustant, M., Dupke, S., Corre, J.-P., Lander, A., Franz, T., et al. (2015). Capsules, toxins and AtxA as virulence factors of emerging Bacillus cereus biovar anthracis. PLoS Negl. Trop. Dis. 9:e0003455. doi: 10.1371/journal. pntd.0003455 group consists of subspecies of the same species of bacteria, it could also be argued that, as the diseases associated with these $B$. cereus strains are caused by the production of anthrax toxin and manifest with classic anthrax symptoms, they should simply be called "anthrax" rather than "anthraxlike."

To conclude, these $B$. cereus strains, traditionally considered foodborne pathogens that establish occasional opportunistic infections, have naturally evolved to cause fatal anthrax-like disease. This serves as a reminder that the field of medical microbiology is constantly changing, posing new challenges that require ongoing vigilance and research.

\section{AUTHOR CONTRIBUTIONS}

$\mathrm{VB}$ researched and wrote the article.

\section{FUNDING}

This study was supported by the United Kingdom Government.

Carroll, L. M., Wiedmann, M., and Kovac, J. (2020). Proposal of a taxonomic nomenclature for the Bacillus cereus group which reconciles genomic definitions of bacterial species with clinical and industrial phenotypes. mBio 11:e00034-20.

Cataldi, A., Mock, M., and Bentancor, L. (2000). Characterization of Bacillus anthracis strains used for vaccination. J. Appl. Microbiol. 88, 648-654. doi: 10.1046/j.1365-2672.2000.01005.x

Centres for Disease Control and Prevention (CDC) (2015). Advice on Anthrax, its Prevention and Treatment. Available online at: https:/www.cdc.gov/anthrax/ basics/index.html (accessed July 23, 2020).

Chang, T., Rosch, J. W., Gu, Z., Hakim, H., Hewitt, C., Gaur, A., et al. (2017). Whole genome characterization of Bacillus cereus associated with specific disease manifestations. Infect. Immun. 86:e00574-17.

Didelot, X., Barker, M., Falush, D., and Priest, F. G. (2009). Evolution of pathogenicity in the Bacillus cereus group. Syst. Appl. Microbiol. 32, 81-90. doi: 10.1016/j.syapm.2009.01.001

Dierick, K., Van Coillie, E., Swiecicka, I., Meyfroidt, G., Devlieger, H., Meulemans, A., et al. (2005). Fatal family outbreak of Bacillus cereus-associated food poisoning. J. Clin. Microbiol. 43, 4277-4279. doi: 10.1128/jcm.43.8.4277-4279. 2005

Dupke, S., Barduhn, A., Franz, T., Leendertz, F. H., Couacy-Hymann, E., Grunow, R., et al. (2019). Analysis of a newly discovered antigen of Bacillus cereus biovar anthracis for its suitability in specific serological antibody testing. J. Appl. Microbiol. 126, 311-323.

Dupke, S., Schubert, G., Beudjé, F., Barduhn, A., Pauly, M., Couacy-Hymann, E., et al. (2020). Serological evidence for human exposure to Bacillus cereus biovar anthracis in the villages around Taï National Park, Côte d'Ivoire. PLoS Negl. Trop. Dis. 14:e0008292. doi: 10.1371/journal.pntd.0008292

European Medicines Agency/ Committee for Human Medicinal Products (EMA/CHMP) (2014). Guidance Document on use of Medicinal Products for the Treatment and Prophylaxis of Biological Agents that Might be used as Weapons of Bioterrorism. Available online at: https://www.ema.europa.eu/en/documents/regulatory-procedural-guideline/ european-medicines-agency/committee-proprietary-medicinal-productsguidance-document-use-medicinal-products-treatment_en.pdf (accessed July 23, 2020)

Fayad, N., Awad, M. K., and Mahillon, J. (2019). Diversity of Bacillus cereus sensu lato mobilome. BMC Genomics 20:436. doi: 10.1186/s12864-0195764-4 
Fieldhouse, R. J., Turgeon, Z., White, D., and Merrill, A. R. (2010). Choleraand anthrax-like toxins are among several new ADP-ribosyltransferases. PLoS Comput. Biol. 6:e1001029. doi: 10.1371/journal.pcbi.1001029

Fouet, A. (2010). AtxA, a Bacillus anthracis global virulence regulator. Res. Microbiol. 161, 735-742. doi: 10.1016/j.resmic.2010.09.006

Fricker, M., Messelhäußer, U., Busch, U., Scherer, S., and Ehling-Schulz, M. (2007). Diagnostic real-time PCR assays for the detection of emetic Bacillus cereus strains in foods and recent food-borne outbreaks. Appl. Environ. Microbiol. 73, 1892-1898. doi: 10.1128/aem.02219-06

Friebe, S., van der Goot, F., and Bürgi, J. (2016). The ins and outs of anthrax toxin. Toxins 8:69. doi: 10.3390/toxins8030069

Gee, J. E., Marston, C. K., Sammons, S. A., Burroughs, M. A., and Hoffmaster, A. R. (2014). Draft genome sequence of Bacillus cereus strain BcFL2013, a clinical isolate similar to G9241. Genome Announc. 2:e00469-14.

Gohar, M., Faegri, K., Perchat, S., Ravnum, S., Økstad, O. A., Gominet, M., et al. (2008). The PlcR virulence regulon of Bacillus cereus. PLoS One 3:e2793. doi: 10.1371/journal.pone.0002793

Granum, P. E., and Lund, T. (1997). Bacillus cereus and its food poisoning toxins. FEMS Microbiol. Lett. 157, 223-228. doi: 10.1111/j.1574-6968.1997.tb12776.x

Grunow, R., Verbeek, L., Jacob, D., Holzmann, T., Birkenfeld, G., Wiens, D., et al. (2012). Injection anthrax-a new outbreak in heroin users. Dtsch. Arztebl. Int. 109, 843-848.

Guinebretière, M. H., Auger, S., Galleron, N., Contzen, M., De Sarrau, B., De Buyser, M. L., et al. (2013). Bacillus cytotoxicus sp. nov. is a novel thermotolerant species of the Bacillus cereus group occasionally associated with food poisoning. Int. J. Syst. Evol. Microbiol. 63, 31-40. doi: 10.1099/ijs.0.030627-0

Guinebretière, M. H., Thompson, F. L., Sorokin, A., Normand, P., Dawyndt, P., Ehling-Schulz, M. et al. (2008). Ecological diversification in the Bacillus cereus Group. Environ. Microbiol. 10, 851-865. doi: 10.1111/j.1462-2920.2007.01495.x

Häggblom, M., Apetroaie, C., Andersson, M. A., and Salkinoja-Salonen, M. S. (2002). Quantitative analysis of cereulide, the emetic toxin of Bacillus cereus, produced under various conditions. Appl. Environ. Microbiol. 68, 2479-2483. doi: 10.1128/aem.68.5.2479-2483.2002

Han, C. S., Xie, G., Challacombe, J. F., Altherr, M. R., Bhotika, S. S., Brown, N., et al. (2006). Pathogenomic sequence analysis of Bacillus cereus and Bacillus thuringiensis isolates closely related to Bacillus anthracis. J. Bacteriol. 188, 3382-3390.

Health Protection Agency [HPA] (2017). Green Book Chapter 13. Available online at: https://assets.publishing.service.gov.uk/government/uploads/system/ uploads/attachment_data/file/593305/Green_Book_Chapter_13.pdf

Hoa, N. T., Baccigalupi, L., Huxham, A., Smertenko, A., Van, P. H., Ammendola, S., Ricca, E., et al. (2000). Characterization of Bacillus species used for oral bacteriotherapy and bacterioprophylaxis of gastrointestinal disorders. Appl. Environ. Microbiol. 66, 5241-5247. doi: 10.1128/aem.66.12.5241-5247.2000

Hoffmann, C., Zimmermann, F., Biek, R., Kuehl, H., Nowak, K., Mundry, R., et al. (2017). Persistent anthrax as a major driver of wildlife mortality in a tropical rainforest. Nature 548, 82-86.

Hoffmaster, A. R., Hill, K. K., Gee, J. E., Marston, C. K., De, B. K., Popovic, T., et al. (2006). Characterization of Bacillus cereus isolates associated with fatal pneumonias: strains are closely related to Bacillus anthracis and harbor B. anthracis virulence genes. J. Clin. Microbiol. 44, 3352-3360. doi: 10.1128/ jcm.00561-06

Hoffmaster, A. R., Ravel, J., Rasko, D. A., Chapman, G. D., Chute, M. D., Marston, C. K., et al. (2004). Identification of anthrax toxin genes in a Bacillus cereus associated with an illness resembling inhalation anthrax. Proc .Natl. Acad. Sci. U.S.A. 101, 8449-8454. doi: 10.1073/pnas.0402414101

Ivanova, N., Sorokin, A., Anderson, I., Galleron, N., Candelon, B., Kapatral, V., et al. (2003). Genome sequence of Bacillus cereus and comparative analysis with Bacillus anthracis. Nature 423, 87-91.

Jackson, P. J., Walthers, E. A., Kalif, A. S., Richmond, K. L., Adair, D. M., Hill, K. K., et al. (1997). Characterization of the variable-number tandem repeats in vrrA from different Bacillus anthracis isolates. Appl. Environ. Microbiol. 63, 1400-1405. doi: 10.1128/aem.63.4.1400-1405.1997

Jiménez, G., Urdiain, M., Cifuentes, A., López-López, A., Blanch, A. R., Tamames, J., et al. (2013). Description of Bacillus toyonensis sp. nov., a novel species of the Bacillus cereus group, and pairwise genome comparisons of the species of the group by means of ANI calculations. Syst. Appl. Microbiol. 36, 383-391. doi: 10.1016/j.syapm.2013.04.008
Johnson, S. L., Daligault, H. E., Davenport, K. W., Jaissle, J., Frey, K. G., Ladner, J. T., et al. (2015). Complete genome sequences for 35 biothreat assay-relevant Bacillus species. Genome Announc. 3:e00151-15.

Jung, M. Y., Kim, J. S., Paek, W. K., Lim, J., Lee, H., Kim, P. I., et al. (2011). Bacillus manliponensis sp. nov., a new member of the Bacillus cereus group isolated from foreshore tidal flat sediment. J. Microbiol. 49, 1027-1032. doi: 10.1007/s12275-011-1049-6

Jung, M. Y., Paek, W. K., Park, I. S., Han, J. R., Sin, Y., Paek, J., et al. (2010). Bacillus gaemokensis sp. nov., isolated from foreshore tidal flat sediment from the Yellow Sea. J. Microbiol. 48, 867-871. doi: 10.1007/s12275-010-0148-0

Kaiser, J. (2011). Updated: University of Chicago Microbiologist Infected from Possible Lab Accident. Science. Available online at: https://www.sciencemag.org/ news/2011/09/updated-university-chicago-microbiologist-infected-possible-la b-accident\#: :text=UPDATED\%3A\%20University\%20of\%20Chicago\%20Micro biologist\%20Infected\%20From\%20Possible\%20Lab\%20Accident,-By\%20Jocel yn\%20Kaiser\&text=The\%20researcher\%20became\%20infected\%20with,Schne ewind\%2C\%20according\%20to\%20the\%20university (accessed July 23, 2020).

Kamal, S., Rashid, A. M., Bakar, M., and Ahad, M. (2011). Anthrax: an update. Asian Pac. J. Trop. Biomed. 1, 496-501.

Keim, P., Gruendike, J. M., Klevytska, A. M., Schupp, J. M., Challacombe, J., and Okinaka, R. (2009). The genome and variation of Bacillus anthracis. Mol. Aspects Med. 30, 397-405. doi: 10.1016/j.mam.2009.08.005

Keim, P., Price, L. B., Klevytska, A. M., Smith, K. L., Schupp, J. M., Okinaka, R., et al. (2000). Multiple-locus variable-number tandem repeat analysis reveals genetic relationships within Bacillus anthracis. J. Bacteriol. 182, 2928-2936. doi: 10.1128/jb.182.10.2928-2936.2000

Klee, S. R., Brzuszkiewicz, E. B., Nattermann, H., Brüggemann, H., Dupke, S., Wollherr, A., et al. (2010). The genome of a Bacillus isolate causing anthrax in chimpanzees combines chromosomal properties of B. cereus with B. anthracis virulence plasmids. PLoS One 5:e10986. doi: 10.1371/journal.pone.001 0986

Klee, S. R., Ozel, M., Appel, B., Boesch, C., Ellerbrok, H., Jacob, D., et al. (2006). Characterization of Bacillus anthracis-like bacteria isolated from wild great apes from Cote d'Ivoire and Cameroon. J. Bacteriol. 188, 5333-5344. doi: 10.1128/ jb.00303-06

Klimpel, K. R., Arora, N., and Leppla, S. H. (1994). Anthrax toxin lethal factor contains a zinc metalloprotease consensus sequence which is required for lethal toxin activity. Mol. Microbiol. 13, 1093-1100. doi: 10.1111/j.1365-2958.1994. tb00500.x

Kolstø, A. B., Tourasse, N. J., and Økstad, O. A. (2009). What sets Bacillus anthracis apart from other Bacillus species? Annu. Rev. Microbiol. 63, 451-476.

Lapidus, A., Goltsman, E., Auger, S., Galleron, N., Ségurens, B., Dossat, C., et al. (2008). Extending the Bacillus cereus group genomics to putative food-borne pathogens of different toxicity. Chem. Biol. Interact. 171, 236-249. doi: 10.1016/ j.cbi.2007.03.003

Lechner, S., Mayr, R., Francis, K. P., Prüss, B. M., Kaplan, T., Wiessner-Gunkel, E., et al. (1998). Bacillus weihenstephanensis sp. nov. is a new psychrotolerant species of the Bacillus cereus group. Int. J. Syst. Bacteriol. 48, 1373-1382. doi: 10.1099/00207713-48-4-1373

Leendertz, F. H., Ellerbrok, H., Boesch, C., Couacy-Hymann, E., Mätz-Rensing, K., Hakenbeck, R., et al. (2004). Anthrax kills wild chimpanzees in a tropical rainforest. Nature 430, 451-452. doi: 10.1038/nature02722

Leendertz, F. H., Yumlu, S., Pauli, G., Boesch, C., Couacy-Hymann, E., Vigilant, L., et al. (2006). A new Bacillus anthracis found in wild chimpanzees and a gorilla from West and Central Africa. PLoS Pathog. 2:e8. doi: 10.1371/journal. ppat.0020008

Leppla, S. H. (1982). Anthrax toxin edema factor: a bacterial adenylate cyclase that increases cyclic AMP concentrations of eukaryotic cells. Proc. Natl. Acad. Sci. U.S.A. 79, 3162-3166. doi: 10.1073/pnas.79.10.3162

Lista, F., Faggioni, G., Valjevac, S., Ciammaruconi, A., Vaissaire, J., le Doujet, C., et al. (2006). Genotyping of Bacillus anthracis strains based on automated capillary 25-loci multiple locus variable-number tandem repeats analysis. $B M C$ Microbiol. 6:33. doi: 10.1186/1471-2180-6-33

Liu, B., Liu, G. H., Hu, G. P., Sengonca, C., Lin, N. Q., Tang, J. Y., et al. (2014). Bacillus bingmayongensis sp. nov., isolated from the pit soil of Emperor Qin's Terra-cotta warriors in China. Antonie Van Leeuwenhoek 105, 501-510. doi: 10.1007/s10482-013-0102-3 
Liu, Y., Lai, Q., Göker, M., Meier-Kolthoff, J. P., Wang, M., Sun, Y., et al. (2015). Genomic insights into the taxonomic status of the Bacillus cereus group. Sci. Rep. 5:14082.

Manchee, R. J., Broster, M. G., Melling, J., Henstridge, R. M., and Stagg, A. J. (1981). Bacillus anthracis on Gruinard Island. Nature 294, 254-255. doi: 10. 1038/294254a0

Manchee, R. J., Broster, M. G., Stagg, A. J., and Hibbs, S. E. (1994). Formaldehyde solution effectively inactivates spores of Bacillus anthracis on the Scottish island of Gruinard. Appl. Environ. Microbiol. 60, 4167-4171. doi: 10.1128/aem.60.11. 4167-4171.1994

Marston, C. K., Ibrahim, H., Lee, P., Churchwell, G., Gumke, M., Stanek, D., et al. (2016). Anthrax toxin-expressing Bacillus cereus isolated from an anthrax-like eschar. PLoS One 11:e0156987. doi: 10.1371/journal.pone.0156987

Mignot, T., Mock, M., Robichon, D., Landier, A., Lereclus, D., and Fouet, A. (2001). The incompatibility between the PlcR- and AtxA-controlled regulons may have selected a nonsense mutation in Bacillus anthracis. Mol. Microbiol. 42, 1189-1198. doi: 10.1046/j.1365-2958.2001.02692.x

Miller, J. M., Hair, J. G., Hebert, M., Herbet, L., Roberts, F. J. Jr., and Weyant, R. S. (1997). Fulminating bacteremia and pneumonia due to B. cereus. J. Clin. Microbiol. 35, 504-507. doi: 10.1128/jcm.35.2.504-507.1997

Miller, R. A., Beno, S. M., Kent, D. J., Carroll, L. M., Martin, N. H., Boor, K. J., et al. (2016). Bacillus wiedmannii sp. nov., a psychrotolerant and cytotoxic Bacillus cereus group species isolated from dairy foods and dairy environments. Int. J. Syst. Evol. Microbiol. 66, 4744-4753. doi: 10.1099/ijsem.0.001421

Moayeri, M., and Leppla, S. H. (2009). Cellular and systemic effects of anthrax lethal toxin and edema toxin. Mol. Aspects Med. 30, 439-455. doi: 10.1016/j. mam.2009.07.003

Moayeri, M., Leppla, S. H., Vrentas, C., Pomerantsev, A. P., and Liu, S. (2015). Anthrax pathogenesis. Annu. Rev. Microbiol. 69, 185-208.

Nakamura, L. K. (1998). Bacillus pseudomycoides sp. nov. Int. J. Syst. Evol. Microbiol. 103:035

Naranjo, M., Denayer, S., Botteldoorn, N., Delbrassinne, L., Veys, J., Waegenaere, J., et al. (2011). Sudden death of a young adult associated with Bacillus cereus food poisoning. J. Clin. Microbiol. 49, 4379-4381. doi: 10.1128/jcm.051 29-11

Oh, S.-Y., Budzik, J. M., Garufi, G., and Schneewind, O. (2011). Two capsular polysaccharides enable Bacillus cereus G9241 to cause anthrax-like disease. Mol. Microbiol. 80, 455-470. doi: 10.1111/j.1365-2958.2011.07582.x

Oh, S. Y., Maier, H., Schroeder, J., Richter, G. S., Elli, D., Musser, J. M., et al. (2013). Vaccine protection against Bacillus cereus-mediated respiratory anthrax-like disease in mice. Infect. Immun. 81, 1008-1017. doi: 10.1128/iai.013 46-12

Okinaka, R. T., Cloud, K., Hampton, O., Hoffmaster, A. R., Hill, K. K., Keim, P., et al. (1999). Sequence and organization of pXO1, the large Bacillus anthracis plasmid harboring the anthrax toxin genes. J. Bacteriol. 181, 6509-6515. doi: 10.1128/jb.181.20.6509-6515.1999

Okinaka, R. T., and Keim, P. (2016). The phylogeny of Bacillus cereus sensu lato. Microbiol. Spectr. 4, 239-251. doi: 10.1128/microbiolspec.TBS-0012-2012

Owusu-Kwarteng, J., Wuni, A., Akabanda, F., Tano-Debrah, K., and Jespersen, L. (2017). Prevalence, virulence factor genes and antibiotic resistance of Bacillus cereus sensu lato isolated from dairy farms and traditional dairy products. BMC Microbiol. 17:65. doi: 10.1186/s12866-017-0975-9

Palmer, J., Bell, M., Darko, C., Barnewall, R., and Keane-Myers, A. (2014). Protein- and DNA-based anthrax toxin vaccines confer protection in guinea pigs against inhalational challenge with Bacillus cereus G9241. Pathog. Dis. 72, $138-142$.

Passalacqua, K. D., Varadarajan, A., Byrd, B., and Bergman, N. H. (2009). Comparative transcriptional profiling of Bacillus cereus Sensu Lato strains during growth in $\mathrm{CO}_{2}$-bicarbonate and aerobic atmospheres. PLoS One 4:e4904. doi: 10.1371/journal.pone.0004904

Pena-Gonzalez, A., Marston, C. K., Rodriguez-R, L. M., Kolton, C. B., GarciaDiaz, J., Theppote, A., et al. (2017). Draft genome sequence of Bacillus cereus LA2007, a human-pathogenic isolate harboring anthrax-like plasmids. Genome Announc. 5:e00181-17.

Pena-Gonzalez, A., Rodriguez-R, L. M., Marston, C. K., Gee, J. E., Gulvik, C. A., Kolton, C. B., et al. (2018). Genomic characterization and copy number variation of Bacillus anthracis plasmids pXO1 and pXO2 in a historical collection of 412 strains. mSystems 3:e00065-18.
Pilo, P., Rossano, A., Bamamga, H., Abdoulkadiri, S., Perreten, V., and Frey, J. (2011). Bovine Bacillus anthracis in Cameroon. Appl. Environ. Microbiol. 77, 5818-5821. doi: 10.1128/aem.00074-11

Public Health England (2014). Guidance for the Management of Cases of Bacillus cereus in view of the Current Neonatal Outbreak in England, June 2014. Available online at: https://www.gov.uk/government/uploads/system/uploads/ attachment_data/file/376396/Guidance_on_the_management_of_cases_of_ Bacillus_cereus.pdf (accessed July 23, 2020).

Read, T. D., Peterson, S. N., Tourasse, N., Baillie, L. W., Paulsen, I. T., Nelson, K. E., et al. (2003). The genome sequence of Bacillus anthracis Ames and comparison to closely related bacteria. Nature $423,81-86$.

Saleh-Lakha, S., Leon-Velarde, C. G., Chen, S., Lee, S., Shannon, K., Fabri, M., et al. (2017). A study to assess the numbers and prevalence of Bacillus cereus and its toxins in pasteurized fluid milk. J. Food Prot. 80, 1085-1089. doi: 10.4315/0362-028x.jfp-16-521

Sastalla, I., Maltese, L. M., Pomerantseva, O. M., Pomerantsev, A. P., KeaneMyers, A., and Leppla, S. H. (2010). Activation of the latent PlcR regulon in Bacillus anthracis. Microbiol 156, 2982-2993. doi: 10.1099/mic.0.041 418-0

Scarff, J. M., Raynor, M. J., Seldina, Y. I., Ventura, C. L., Koehler, T. M., and O'Brien, A. D. (2016). The roles of AtxA orthologs in virulence of anthraxlike Bacillus cereus G9241. Mol. Microbiol. 102, 545-561. doi: 10.1111/mmi. 13478

Scarff, J. M., Seldina, Y. I., Vergis, J. M., Ventura, C. L., and O’Brien, A. D. (2018). Expression and contribution to virulence of each polysaccharide capsule of Bacillus cereus strain G9241. PLoS One 13:e0202701. doi: 10.1371/journal.pone. 0202701

Schmidt, T. R., Scott, E. J., and Dyer, D. W. (2011). Whole-genome phylogenies of the family Bacillaceae and expansion of the sigma factor gene family in the Bacillus cereus species-group. BMC Genomics 12:430. doi: 10.1186/1471-2164$12-430$

Scorpio, A., Chabot, D. J., Day, W. A., Hoover, T. A., and Friedlander, A. M. (2010). Capsule depolymerase overexpression reduces Bacillus anthracis virulence. Microbiol 156, 1459-1467. doi: 10.1099/mic.0.035 $857-0$

Scorpio, A., Chabot, D. J., Day, W. A., O’Brien, D. K., Vietri, N. J., Itoh, Y., et al. (2007). Poly-gamma-glutamate capsule-degrading enzyme treatment enhances phagocytosis and killing of encapsulated Bacillus anthracis. Antimicrob. Agents Chemother. 51, 215-222.

Seldina, Y. I., Petro, C. D., Servetas, S. L., Vergis, J. M., Ventura, C. L., Merrell, D. S., et al. (2018). Certhrax is an anti-virulence factor for the anthrax-like organism Bacillus cereus strain G9241. Infect. Immun. 86, e207-e218.

Senesi, S., and Ghelardi, E. (2010). Production, secretion and biological activity of Bacillus cereus enterotoxins. Toxins 2, 1690-1703. doi: 10.3390/toxins207 1690

Shawish, R., and Tarabees, R. (2017). Prevalence and antimicrobial resistance of Bacillus cereus isolated from beef products in Egypt. Open Vet. J. 7, 337-341.

Simon, N. C., and Barbieri, J. T. (2014). Bacillus cereus certhrax ADP-ribosylates vinculin to disrupt focal adhesion complexes and cell adhesion. J. Biol. Chem. 289, 10650-10659. doi: 10.1074/jbc.m113.500710

Simon, N. C., Vergis, J. M., Ebrahimi, A. V., Ventura, C. L., O’Brien, A. D., and Barbieri, J. T. (2013). Host cell cytotoxicity and cytoskeleton disruption by CerADPr, an ADP-ribosyltransferase of Bacillus cereus G9241. Biochem 52, 2309-2318. doi: 10.1021/bi300692g

Slamti, L., Perchat, S., Gominet, M., Vilas-Bôas, G., Fouet, A., Mock, M., et al. (2004). Distinct mutations in PlcR explain why some strains of the Bacillus cereus group are nonhemolytic. J. Bacteriol. 186, 3531-3538. doi: 10.1128/jb. 186.11.3531-3538.2004

Sue, D., Hoffmaster, A. R., Popovic, T., and Wilkins, P. P. (2006). Capsule production in Bacillus cereus strains associated with severe pneumonia. J. Clin. Microbiol. 44, 3426-3428. doi: 10.1128/jcm.00873-06

Swick, M. C., Koehler, T. M., and Driks, A. (2016). Survivng between hosts: sporulation and transmission. Microbiol. Spectr. 4:10.1128/microbiolsec.VMBF-0029-2015.

Thierry, S., Tourterel, C., Le Flèche, P., Derzelle, S., Dekhil, N., Mendy, C., et al. (2014). Genotyping of French Bacillus anthracis strains based on 31-loci multi locus VNTR analysis: epidemiology, marker evaluation, and update of the 
internet genotype database. PLoS One 9:e95131. doi: 10.1371/journal.pone. 0095131

Tourasse, N. J., Økstad, O. A., and Kolstø, A.-B. (2010). HyperCAT: an extension of the SuperCAT database for global multi-scheme and multidatatype phylogenetic analysis of the Bacillus cereus group population. Database 2010:017.

Tournier, J. N., Rougeaux, C., Biot, F. V., and Goossens, P. L. (2019). Questionable efficacy of therapeutic antibodies in the treatment of anthrax. mSphere 4:e00282-19.

Uchida, I., Sekizaki, T., Hashimoto, K., and Terakado, N. (1985). Association of the encapsulation of Bacillus anthracis with a 60 megadalton plasmid. J. Gen. Microbiol. 131, 363-367. doi: 10.1099/00221287-131-2-363

US Food and Drug Administration (FDA) (2008). Doxycycline Datasheet. Available online at: https://www.accessdata.fda.gov/drugsatfda_docs/label/ 2008/050795s005lbl.pdf

US Food and Drug Administration (FDA) (2016). Ciprofloxacin Datasheet. Available online at: https://www.accessdata.fda.gov/drugsatfda_docs/label/ 2016/019537s086lbl.pdf

Vietri, N. J. (2018). Does anthrax antitoxin therapy have a role in the treatment of inhalational anthrax? Curr. Opin. Infect. Dis. 31, 257-262. doi: 10.1097/qco. 0000000000000446

Visschedyk, D., Rochon, A., Tempel, W., Dimov, S., Park, H. W., and Merrill, A. R. (2012). Certhrax toxin, an anthrax-related ADP-ribosyltransferase from Bacillus cereus. J. Biol. Chem. 287, 41089-41102. doi: 10.1074/jbc.m112.41 2809

Wang, Y. T., Oh, S. Y., Hendrickx, A. P., Lunderberg, J. M., and Schneewind, O. (2013). Bacillus cereus G9241 S-layer assembly contributes to the pathogenesis of anthrax-like disease in mice. J. Bacteriol. 195, 596-605. doi: 10.1128/jb. 02005- 12

Wijnands, L. M., Dufrenne, J. B., Rombouts, F. M., Veld, P. H., and van Leusden, F. M. (2006). Prevalence of potentially pathogenic Bacillus cereus in food commodities in The Netherlands. J. Food Prot. 69, 2587-2594. doi: 10.4315/ 0362-028x-69.11.2587
Wilson, M. K., Vergis, J. M., Alem, F., Palmer, J. R., Keane-Myers, A. M., Brahmbhatt, T. N., et al. (2011). Bacillus cereus G9241 makes anthrax toxin and capsule like highly virulent $B$. anthracis Ames but behaves like attenuated toxigenic nonencapsulated $B$. anthracis Sterne in rabbits and mice. Infect. Immun. 79, 3012-3019. doi: 10.1128/iai.00205-11

Wright, A. M., Beres, S. B., Consamus, E. N., Long, S. W., Flores, A. R., Barrios, R., et al. (2011). Rapidly progressive, fatal, inhalation anthrax-like infection in a human: case report, pathogen genome sequencing, pathology, and coordinated response. Arch. Pathol. Lab. Med. 135, 1447-1459. doi: 10.5858/2011-0362sair.1

Young, J. A., and Collier, R. J. (2007). Anthrax toxin: receptor binding, internalization, pore formation, and translocation. Annu. Rev. Biochem. 76, 243-265. doi: 10.1146/annurev.biochem.75.103004.142728

Zimmermann, F., Köhler, S. M., Nowak, K., Dupke, S., Barduhn, A., Düx, A., et al. (2017). Low antibody prevalence against Bacillus cereus biovar anthracis in Taï National Park, Côte d'Ivoire, indicates high rate of lethal infections in wildlife. PLoS Negl. Trop. Dis. 11:e0005960. doi: 10.1371/journal.pntd.000 5960

Zwick, M. E., Joseph, S. J., Didelot, X., Chen, P. E., Bishop-Lilly, K. A., Stewart, A. C., et al. (2012). Genomic characterization of the Bacillus cereus sensu lato species: Backdrop to the evolution of Bacillus anthracis. Genome Res. 22, 1512-1524. doi: $10.1101 /$ gr.134437.111

Conflict of Interest: The author declares that the research was conducted in the absence of any commercial or financial relationships that could be construed as a potential conflict of interest.

Crown copyright (C) (2020), Dstl. Author: Baldwin. This is an open-access article distributed under the terms of the Creative Commons Attribution License (CC BY). The use, distribution or reproduction in other forums is permitted, provided the original author(s) and the copyright owner(s) are credited and that the original publication in this journal is cited, in accordance with accepted academic practice. No use, distribution or reproduction is permitted which does not comply with these terms. 